\title{
Physical and chemical characteristics of 1300 lakes and ponds across the Canadian Arctic
}

\author{
Tanner Liang*, Julian Aherne
}

School of the Environment, Trent University, Peterborough, Ontario, Canada K9L 0G2

\begin{abstract}
Lakes and ponds are a major feature of the Arctic landscape and are recognized as effective 'sentinels of change'. Here we present water chemistry characteristics of lakes and ponds ( $\mathrm{n}=1300$ with 26 variables) across the Canadian Arctic collated from published studies. We also extracted geological and ecoregion data in an attempt to determine the key drivers. In general, most lakes were shallow $(85.4 \%,<10 \mathrm{~m})$, nutrient (phosphorus) poor (oligotrophic $=45.6 \%$ and ultra-oligotrophic $=24.8 \%)$, located at low elevation $(66.5 \%$, $<200 \mathrm{~m}$ asl), close to coastlines $(72.5 \%, 0-50 \mathrm{~km})$, and underlain by sedimentary geology $(66.5 \%)$. The first two components from Principal Component Analysis explained $49.3 \%$ of the variation in the dataset; the first component was dominated by conductivity/carbonate materials, and the second component suggested allochthonous inputs of phosphorus. In general, bedrock geology is the primary driver of water chemistry; as such, there were major differences between lakes underlain by igneous and sedimentary rocks. Those on sedimentary bedrock tend to have higher $\mathrm{pH}$, nutrients and higher inorganic ion concentrations.
\end{abstract}

\section{INTRODUCTION}

Lentic systems, i.e., freshwater lakes and ponds, are a major feature of the Arctic and Subarctic landscape. It is estimated that there are approximately 3.5 million lakes and ponds within the Arctic circle $\left(\geq 66.6^{\circ} \mathrm{N}\right)$ with $>40 \%$ located within the Canadian Arctic (Paltan et al., 2015). The vast majority of these aquatic systems are generally small ( $<10 \mathrm{ha})$ and shallow $(<12 \mathrm{~m}$ in depth) ponds (Hamilton et al., 2001; Rautio et al., 2011; Paltan et al., 2015; Dranga et al., 2018), but they can also be large and deep systems (e.g., Great Bear Lake in Northwest Territories at $114,717 \mathrm{~km}^{2}$ and max depth 446 $\mathrm{m}$ (Vincent et al., 2012). Arctic lakes and ponds are exposed to harsh climatic conditions, i.e., low temperatures, low precipitation volume, and seasonally low inputs of solar radiation, which limit the development of vegetation and the chemical weathering

Corresponding author: tannerliang@trentu.ca

Key words: Limnology; water chemistry; nutrients; metals; geology; arctic lakes.

Edited by: Michela Rogora, CNR-IRSA Verbania, Italy.

Received: 16 June 2020

Accepted: 13 August 2020.

This work is licensed under a Creative Commons Attribution NonCommercial 4.0 License (CC BY-NC 4.0).

${ }^{\circ}$ Copyright: the Author(s), 2020

Licensee PAGEPress, Italy

J. Limnol., 2020; 79(3): 254-277

DOI: 10.4081/jlimnol.2020.1973 of soils within lake catchments. Most precipitation occurs in the form of snow or ice (Maxwell, 1981) and during the melting period brings large amounts of water and other components (particulates and dissolved compounds) into these (often isolated) systems, which results in dilute systems that are further modified by terrestrial processes. This runoff-dominated region results in lakes and ponds with hydrochemical characteristics that are unique to the Arctic (Hamilton et al., 2001; Wetzel, 2001; Lamoureux and Gilbert, 2004). These systems provide vital habitat for many biological communities. In addition, they provide resources (hunting, fishing, and drinking water) for Indigenous communities. Moreover, it is well established that aquatic systems, such as lakes and ponds, are effective indicators or 'sentinels of change', as they reflect process changes at the catchment scale, and can provide spatial and temporal information on the impacts of anthropogenic activity (Adrian et al., 2009). Previous studies have shown (anthropogenic driven) local (wastewater discharge, Schindler et al.,1974; road dust, Gunter, 2017; industrial development, Moiseenko et al., 2009), regional (atmospheric deposition of contaminants, Outridge et al., 2001; nitrogen deposition, Wolfe et al., 2006), and global (Smith et al., 2005; Michelutti et al., 2007b; Adams et al., 2010; Thienpont et al., 2013) scale impacts on the physical and chemical characteristics of Arctic lakes. Although there have been many limnological studies in the Canadian Arctic (Pienitz et al., 1997a, 1997b; Rühland et al., 1998; Hamilton et al., 2011; Michelutti et al., 2002a, 2002b; Lim and Douglas, 2003; Antoniades et al., 2003a, 2003b; Mallory et al., 2006; Westover et al., 2009; Côté et al., 2010; Stewart and Lamoureux, 2011; Medeiros et al., 2012; Robert et al., 2017), few studies have integrated existing observations to provide baseline limnological data required for regional 
assessments (Hamilton et al., 2010; Dranga et al., 2018; Liang and Aherne, 2019).

The objective of this study was to provide a broad assessment of the physical and chemical characteristics of lakes and ponds among the different geographic, geological, and ecological regions across the Canadian Arctic (for 1300 sites), and to evaluate the drivers of water chemistry. This was carried out by collating published hydrochemical data for 1300 sites from 33 peer-reviewed articles. We utilized a similar approach to that of Hamilton et al. (2010) and Dranga et al. (2018); however, we limited our geographic scope to the Canadian region in the Arctic Monitoring \& Assessment Programme circumpolar boundary (Stonehouse, 1989; AMAP, 1998) and included recent hydrochemical data from Liang and Aherne (2019). In general, the study sites were primarily located in remote background regions with limited direct anthropogenic disturbance, as such they are potentially sentinels of climate change, land-use disturbance and anthropogenic pollutant deposition (e.g., trace metals, and acidic and nutrient deposition).

\section{METHODS}

\section{Study area}

The Canadian Arctic (Canadian territory within the boundary of the Arctic Monitoring and Assessment Program; Stonehouse, 1989) is approximately $4.0 \times 10^{6}$ $\mathrm{km}^{2}$ (AMAP, 1998) covering all areas north of $60^{\circ} \mathrm{N}$. This includes the Canadian Arctic Archipelago, the territory of Yukon, Northwest Territories and Nunavut, and parts of northern Quebec and Labrador (Fig. 1). Much of the Canadian Arctic Archipelago region rests upon the Arctic Platform, which consists of sedimentary geology comprised of shale, siltstone, sandstone, limestone and dolomite (Clague et al., 1989; Dawes and Christie, 1991; Fig. 2 Top). The eastern perimeter (eastern Ellesmere, eastern Devon, Baffin Is., eastern Northwest Territories, Nunavut, northern Quebec, and northern Labrador) rests upon Precambrian (Canadian) Shield, which consist of igneous crystalline and metamorphic rock, that includes greenstone, gabbro, gneisses, granitic, and volcanic rocks

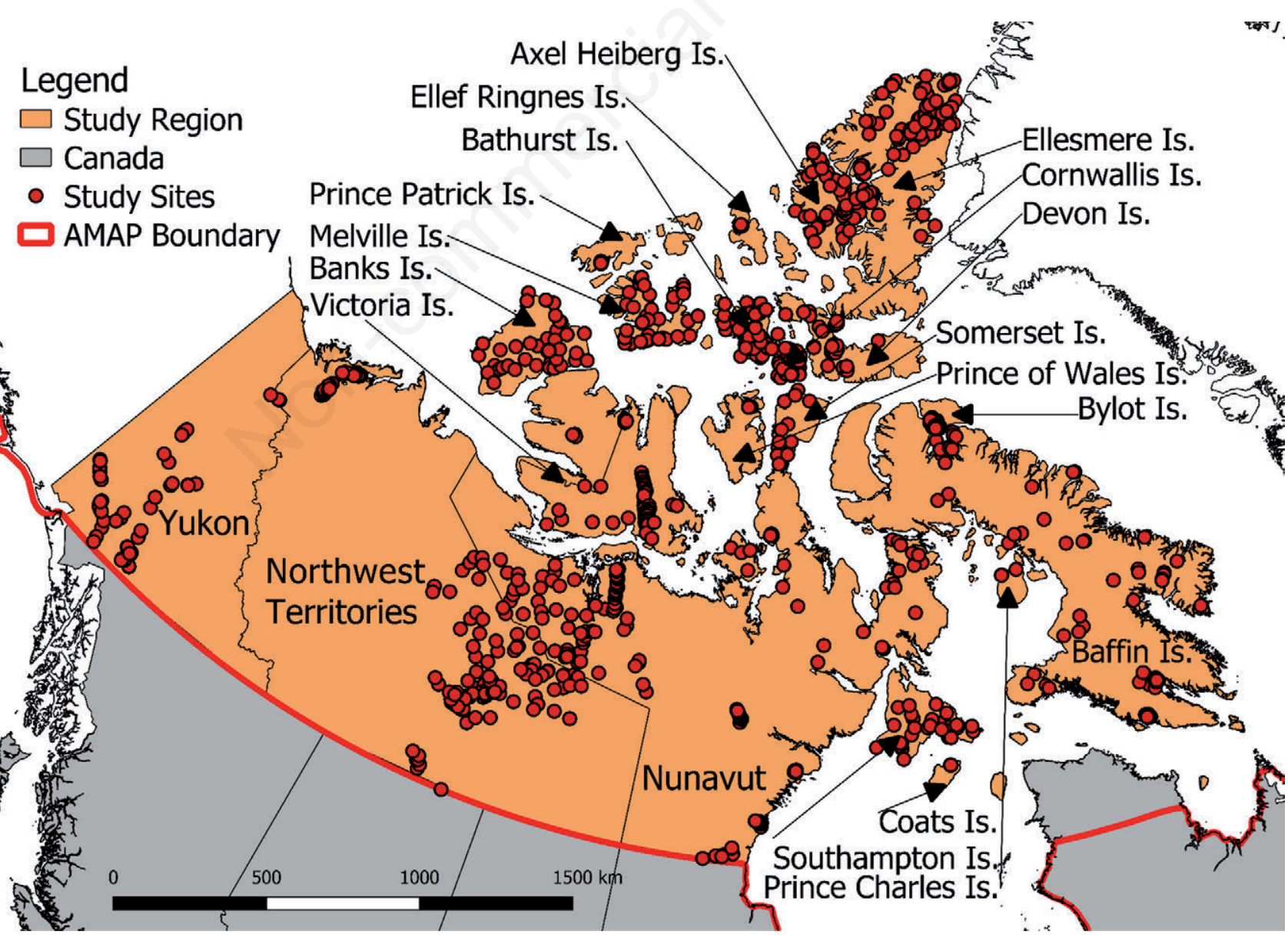

Fig. 1. Names of islands and regions within the study area; the AMAP boundary is depicted as a red line (taken from AMAP, 1998), while study sites are depicted as red dots. 


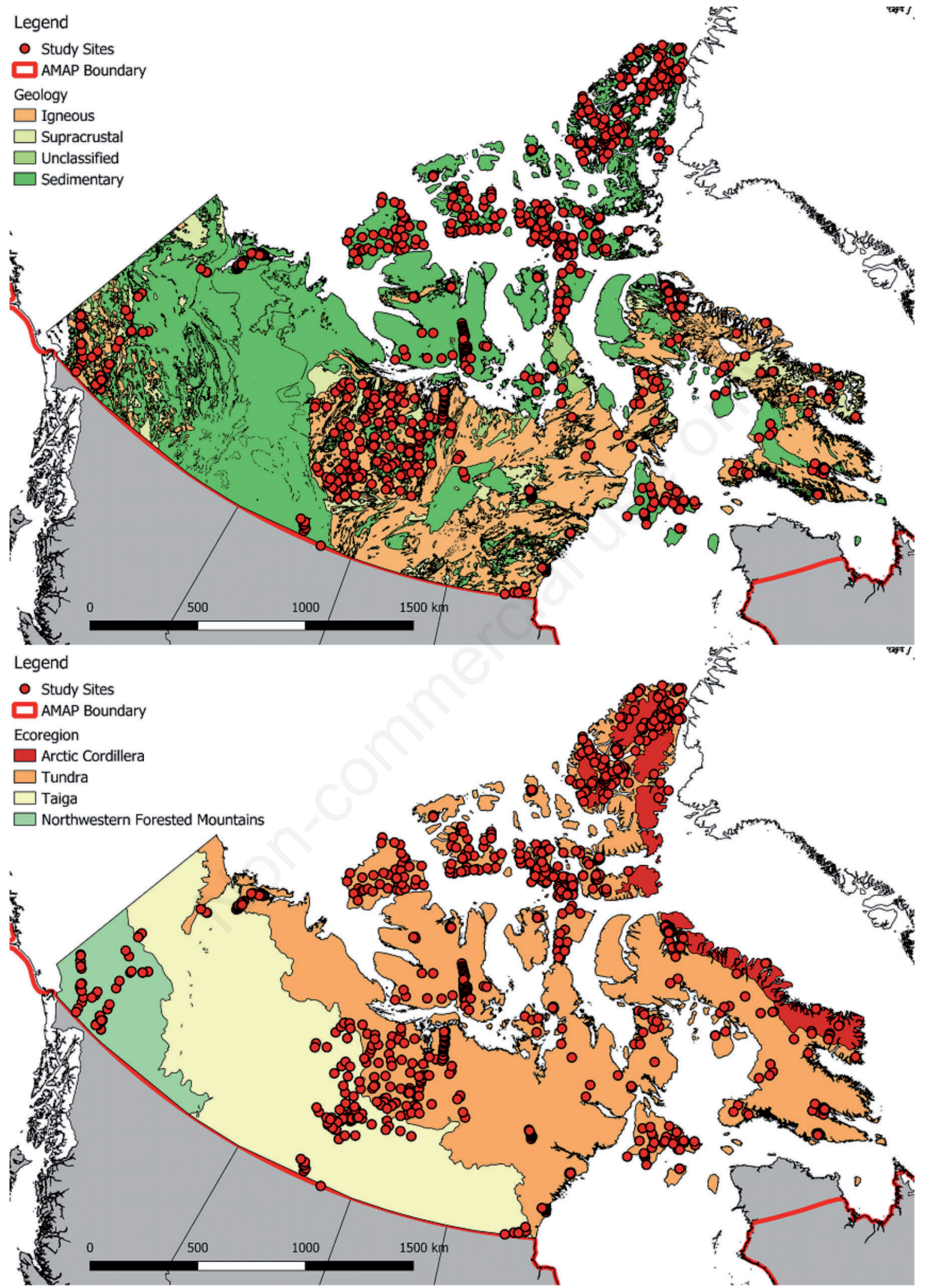

Fig. 2. Location of all study sites (red dots) superimposed on bedrock geology (top) from Harrison et al. (2011) and ecoregion type (bottom) from CEC (1997). 
(Clague et al., 1989; Dawes and Christie, 1991; Harris et al., 2012; Fig. 2 Top). In general, arctic soils are poorly developed and greatly influenced by cryogenic processes (the formation of ice in soils), such as freeze-thaw, ice build-up, thermal cracking, and frost heave, which leads to poorly defined soil horizons (Tarnocai, 2009). Soil chemical properties are greatly influenced by their parent material, although soil nutrients (N, P, K) are generally bound up by surface organics (Tarnocai, 2009). Peat bogs and organic soils are common among depressions in the southern Arctic landscape and are the result of accumulated plant growth (Tarnocai, 2009). The study area encompassed four ecoregions (CEC, 1997): Arctic Cordillera (AC), Tundra (TU), Taiga (TA), and Northwestern Forested (NWF) mountains (Fig. 2 Bottom), which are geographical units with characteristic flora, fauna and ecosystems (CEC, 1997). The AC consists of the mountainous regions of the eastern Arctic, while the TU covers most of the Canadian Arctic Archipelago (CEC, 1997). The TA ecoregion is south of the TU and encompasses the tree line, while the NWF mostly lies in the southwestern portion of the study area (CEC, 1997). Low temperatures and precipitation, long winters, short summers, and extreme seasonal light exposure ( $24 \mathrm{hrs}$ of darkness in the winter and light during the summer) are common climate characteristics of the Arctic. Climatic conditions vary among regions (Maxwell, 1981), with colder temperatures occurring in the north $\left(-28\right.$ to $-35^{\circ} \mathrm{C}$ in January and $0-3^{\circ} \mathrm{C}$ in July), compared with the south $\left(-20\right.$ to $-25^{\circ} \mathrm{C}$ in the winter and 5 to $8^{\circ} \mathrm{C}$ in July). Similarly, precipitation ranges from $<100 \mathrm{~mm}$ in the north, to $200-500 \mathrm{~mm}$ annually in the south, with much of the precipitation (20-50\%) falling as snow or ice (Maxwell, 1981).

\section{Arctic water chemistry dataset}

Published articles $(\mathrm{n}=28)$, reports $(\mathrm{n}=2)$, and graduate theses $(n=3)$ containing water chemistry observations for Arctic lakes and ponds were compiled into a single dataset; the initial database had more than 1600 observations, including overlapping sites. Studies that presented the hydrochemistry of streams and rivers (Babaluk et al., 1999, 2009) were removed as the focus was on lakes and ponds. In addition, some studies presented sites below the AMAP boundary $\left(60^{\circ} \mathrm{N}\right)$, these were also removed. The most recent sampling period was chosen to represent sites with multiple observation and duplicate datasets were removed (i.e., same datapoints were reported in multiple studies). After accounting for overlaps and duplicates, the final dataset was composed of 1300 unique sites (Tab. 1; Fig. 1). Site selection in most studies in the Canadian Arctic is limited by logistical and climatic conditions; as such, sites were primarily sampled during the ice-free season of July and August; details on sampling and analytical methods can be found in their corresponding papers (Tab. 1). In general, most studies followed analytical methods as outlined by Environment and Climate Change Canada (ECCC, 1994a, b). A large portion of sites were sampled in the years $1993(\mathrm{n}=185)$, $2003(\mathrm{n}=101)$, and $2016(\mathrm{n}=81)$ (Tab. 3). However, some studies only reported a year range for their sampling date, i.e., 1989-2002 (Bouchard et al., 2004) and 2006-2010 (Medeiros et al., 2012), as such, the exact sampling dates were unknown. This accounted for $\sim 10 \%(\mathrm{n}=176)$ of sites. The earliest observation reported was 1979 on Ellesmere Is. (Hamilton et al., 2001), whereas the most

Tab. 1. List of published sources with water chemistry data and their respective surface water site count.

\begin{tabular}{|c|c|c|}
\hline No. & Source & Site count \\
\hline 1 & Antoniades et al. (2003a) & 66 \\
\hline 2 & Antoniades et al. (2003b) & 25 \\
\hline 3 & Babaluk et al. (1999) & 8 \\
\hline 4 & Babaluk et al. (2009) & 14 \\
\hline 5 & Bouchard et al. (2004) & 48 \\
\hline 6 & Brimble et al. (2009) & 26 \\
\hline 7 & Bunbury and Gajewski (2009) & 9 \\
\hline 8 & Bunbury and Gajewski (2005) & 33 \\
\hline 9 & Côte et al. (2010) & 27 \\
\hline 10 & Delvin MSc 2010) & 20 \\
\hline 11 & Hadley et al. (2013) & 40 \\
\hline 12 & Hadley MSc 2007) & 6 \\
\hline 13 & Hamilton et al. (2001) & 181 \\
\hline 14 & Keatley et al. (2007) & 55 \\
\hline 15 & Keatley Ph.D (2007) & 46 \\
\hline 16 & Liang and Aherne (2019) & 100 \\
\hline 17 & Lim and Douglas (2003 & 23 \\
\hline 18 & Lim et al. (2005) & 45 \\
\hline 19 & Lim et al. (2001) & 9 \\
\hline 20 & Mallory et al. (2006) & 32 \\
\hline 21 & Medeiros et al. (2012) & 93 \\
\hline 22 & Michelutti et al. (2002a) & 34 \\
\hline 23 & Michelutti et al. (2002b) & 38 \\
\hline 24 & Michelutti et al. (2007) & 33 \\
\hline 25 & Michelutti et al. (2010) & 2 \\
\hline 26 & Moser et al. (1993) & 8 \\
\hline 27 & Pienitz et al. (1997a) & 59 \\
\hline 28 & Pienitz et al. (1997b) & 24 \\
\hline 29 & Ruhland and Smol (1998) & 70 \\
\hline 30 & Ruhland et al. (2003) & 56 \\
\hline 31 & Stewart and Lamoureux (2011) & 2 \\
\hline 32 & Westover et al. (2009) & 61 \\
\hline 33 & Wilson and Gajewski (2002) & 7 \\
\hline Total & & 1300 \\
\hline
\end{tabular}


recent observations were from 2016 on Baffin Is. (Liang and Aherne, 2019; Tab. 3).

The initial database had more than 90 physical and chemical variables. Observations below detection, primarily trace element concentrations, were assigned a random number between zero and the associated detection limit. Total nitrogen (TN) concentration was calculated as the sum of total kjeldahl nitrogen (TKN: organic nitrogen + ammonia), nitrates $\left(\mathrm{NO}_{3}\right)$, and nitrites $\left(\mathrm{NO}_{2}\right)$, when data for TKN, $\mathrm{NO}_{3}$, and $\mathrm{NO}_{2}$ were available but few observations for nitrate $\left(\mathrm{NO}_{3} ; \mathrm{n}=74\right)$ were reported. In addition, some parameters were reported as filtered and unfiltered. An average value was calculated between filtered and unfiltered samples, and these variables were denoted with an asterisk, i.e., $\mathrm{NH}_{3}{ }^{*}, \mathrm{TP}^{*}, \mathrm{TKN}^{*}, \mathrm{TN}^{*}$, $\mathrm{NO}_{3}{ }^{*}, \mathrm{NO}_{2}{ }^{*}$, etc. Other variables (i.e., depth, TSS, Chlaa, $\mathrm{Cu}, \mathrm{Ni}, \mathrm{Se}, \mathrm{U}$, etc.) are reported in the supporting material (Supporting Material T1).

Physical (location, elevation, depth, area) and chemical data for each site were extracted and unified into a common data structure. Missing values for elevation (m) were determined using Google Maps' Elevation
Application Programming Interface. Distance to coast $(\mathrm{km})$ was calculated using the Grass GIS 7 plugin in QGIS and a coastal shapefile of Canada. Geological data were obtained from Harrison et al. (2012), while ecoregion information was obtained from CEC (1997). In general, individual datasets did not have similar unit systems, i.e., coordinate systems (decimal degrees $v s$ degree minute seconds), concentration ( $\left.\mu \mathrm{g} \mathrm{L}^{-1} v s \mathrm{mg} \mathrm{L}^{-1}\right)$, or a consistent suite of chemical parameters. Physical and chemical parameters $(\mathrm{n}=26)$ with an observation count $\geq 700(>50 \%$ of 1300 sites) were selected for further analysis, these were: Latitude, Longitude, elevation, distance to coast, lake area, $\mathrm{pH}$, conductivity, $\mathrm{Ca}, \mathrm{K}, \mathrm{Mg}, \mathrm{Na}, \mathrm{Cl}, \mathrm{SO}_{4}, \mathrm{SiO}_{2}$, DOC, POC, DIC, $\mathrm{NH}_{3}, \mathrm{TKN}, \mathrm{TN}, \mathrm{TP}, \mathrm{Al}, \mathrm{Ba}, \mathrm{Fe}, \mathrm{Mn}$, and Sr. See Supporting Material for figures depicting the location of sites used for the analysis of cations $(\mathrm{Ca}, \mathrm{Mg}$, $\mathrm{Na}, \mathrm{K}$; Supporting Material $\mathrm{F} 4)$, anions $\left(\mathrm{Cl}, \mathrm{SO}_{4}\right.$; Supporting Material F5), nutrients (TP, TN, DOC; Supporting Material F6), and trace metals (Al, Fe, Mn; Supporting Material F7). Sites were included in the analysis if one or more ion/nutrient/trace metal species were available.

Tab. 2. Descriptive statistics for Arctic lakes and ponds $(\mathrm{n} \leq 1300)$ for 26 variables including unit, count, mean, percent coefficient of variation $(\% \mathrm{CV})$, minimum, maximum, and percentile $\left(5^{\text {th }}\right.$ and $\left.9^{\text {th }}\right)$ values.

\begin{tabular}{|c|c|c|c|c|c|c|c|c|c|c|}
\hline \multirow[b]{2}{*}{ Variable } & \multirow[b]{2}{*}{ Symbol } & \multirow[b]{2}{*}{ Unit } & \multirow[b]{2}{*}{ Count } & \multirow[b]{2}{*}{ Mean } & \multirow[b]{2}{*}{$\% \mathrm{CV}$} & \multirow[b]{2}{*}{ Min } & \multirow[b]{2}{*}{ Max } & \multirow[b]{2}{*}{ Median } & \multicolumn{2}{|c|}{ Percentile } \\
\hline & & & & & & & & & $5^{\text {th }}$ & $95^{\text {th }}$ \\
\hline Elevation & Elev & $\mathrm{m}$ asl & 1300 & 198 & 216.9 & 0 & 1387 & 134 & 7.9 & 657 \\
\hline Distance to coast & DistC & $\mathrm{km}$ & 1300 & 69.4 & 780.2 & 0.01 & 750 & 13.5 & 0.56 & 395 \\
\hline Area & Area & ha & 877 & 1088 & 7594.1 & 0 & 506300 & 6.38 & 0.03 & 553 \\
\hline $\mathrm{pH}$ & $\mathrm{pH}$ & & 1253 & 6.01 & 0.003 & 10.9 & 3.4 & 7.9 & 8.7 & 6.31 \\
\hline Conductivity & Cond & $\mu \mathrm{S} \cdot \mathrm{cm}^{-1}$ & 1235 & 186 & 193.2 & 1.46 & 13200 & 97.4 & 9.61 & 554 \\
\hline Calcium & $\mathrm{Ca}$ & $\mathrm{mg} \cdot \mathrm{L}^{-1}$ & 1253 & 20.5 & 257.3 & 0 & 451 & 14.6 & 0.67 & 52.4 \\
\hline Potassium & K & $\mathrm{mg} \cdot \mathrm{L}^{-1}$ & 1208 & 1.61 & 246.5 & 0 & 109 & 0.57 & 0.11 & 5.97 \\
\hline Magnesium & $\mathrm{Mg}$ & $\mathrm{mg} \cdot \mathrm{L}^{-1}$ & 1144 & 8.24 & 195.1 & 0.01 & 273 & 3.7 & 0.32 & 28.2 \\
\hline Sodium & $\mathrm{Na}$ & $\mathrm{mg} \cdot \mathrm{L}^{-1}$ & 1255 & 12.3 & 313.1 & 0.01 & 1650 & 1.65 & 0.3 & 35.1 \\
\hline Chloride & $\mathrm{Cl}$ & $\mathrm{mg} \cdot \mathrm{L}^{-1}$ & 1251 & 16.2 & 357.5 & 0 & 2850 & 2.05 & 0.3 & 44.5 \\
\hline Sulphate & $\mathrm{SO}_{4}$ & $\mathrm{mg} \cdot \mathrm{L}^{-1}$ & 1251 & 28.7 & 405.6 & 0.03 & 2100 & 3.1 & 0.4 & 117 \\
\hline Silica & $\mathrm{SiO}_{2}$ & $\mathrm{mg} \cdot \mathrm{L}^{-1}$ & 984 & 1.04 & 207.8 & 0 & 13.9 & 0.51 & 0.07 & 3.7 \\
\hline Dissolve organic carbon & DOC & $\mathrm{mg} \cdot \mathrm{L}^{-1}$ & 1130 & 5.73 & 140.1 & 0.02 & 69.9 & 3.5 & 0.69 & 18.0 \\
\hline Dissolve inorganic carbon & DIC & $\mathrm{mg} \cdot \mathrm{L}^{-1}$ & 1032 & 13.8 & 192 & 0.06 & 134 & 10.9 & 0.7 & 36.5 \\
\hline Particulate organic carbon & POC & $\mathrm{mg} \cdot \mathrm{L}^{-1}$ & 702 & 0.56 & 87.6 & 0.01 & 9.89 & 0.41 & 0.12 & 1.34 \\
\hline Ammonia & $\mathrm{NH}_{3} *$ & $\mu \mathrm{g} \cdot \mathrm{L}^{-1}$ & 744 & 25.1 & 175.4 & 0.06 & 459 & 12 & 2 & 83.9 \\
\hline Total Kjeldahl nitrogen & $\mathrm{TKN}^{*}$ & $\mu \mathrm{g} \cdot \mathrm{L}^{-1}$ & 802 & 376 & 192.4 & 0.06 & 2760 & 263 & 49.05 & 1100 \\
\hline Total nitrogen & $\mathrm{TN}^{*}$ & $\mu \mathrm{g} \cdot \mathrm{L}^{-1}$ & 864 & 424 & 105.5 & 7.4 & 5324 & 312 & 71.8 & 1068 \\
\hline Total phosphorous & TP* & $\mu \mathrm{g} \cdot \mathrm{L}^{-1}$ & 1247 & 11.14 & 121.8 & 0 & 761 & 7.05 & 1.35 & 28.1 \\
\hline Aluminum & $\mathrm{Al}$ & $\mu \mathrm{g} \cdot \mathrm{L}^{-1}$ & 872 & 113 & 314.3 & 0.02 & 11200 & 17 & 2.76 & 328 \\
\hline Barium & $\mathrm{Ba}$ & $\mu \mathrm{g} \cdot \mathrm{L}^{-1}$ & 814 & 14.3 & 173.4 & 0.15 & 272 & 6.45 & 1 & 54 \\
\hline Iron & $\mathrm{Fe}$ & $\mu \mathrm{g} \cdot \mathrm{L}^{-1}$ & 1015 & 199 & 405.3 & 0.03 & 11500 & 48 & 3 & 765 \\
\hline Manganese & $\mathrm{Mn}$ & $\mu \mathrm{g} \cdot \mathrm{L}^{-1}$ & 875 & 529 & 1244.6 & 0 & 52600 & 5.3 & 0.46 & 2490 \\
\hline Strontium & $\mathrm{Sr}$ & $\mu \mathrm{g} \cdot \mathrm{L}^{-1}$ & 819 & 72 & 223.1 & 0.24 & 3150 & 23.9 & 3.09 & 245 \\
\hline
\end{tabular}


An ion balance check was used to assess the quality of water chemistry data following the International Cooperative Programme for assessment and monitoring of the effects of air pollution on rivers and lakes (ICP Waters, 2010). Only 224 sites (17.2\%) had complete observations of $\mathrm{Ca}, \mathrm{Mg}, \mathrm{Na}, \mathrm{K}, \mathrm{ALK}, \mathrm{Cl}, \mathrm{NO}_{3}, \mathrm{SO}_{4}$, and $\mathrm{pH}$, to perform the ion balance (see Supporting Material F 2). Only 13 of the 224 sites (6.27\%) had differences $>10 \%$ and were deemed unacceptable.

The $\mathrm{Na}$ and $\mathrm{Cl}$ ratio can be used to assess the dominance of inputs from marine aerosols, where 0.86 is the ( $\mu$ eq $\left.\mathrm{L}^{-1}\right)$ ratio for seawater (Möller, 1990). A $\mathrm{Na}: \mathrm{Cl}$ ratio $>0.86$ suggests that surface waters may be influenced by terrestrial inputs of $\mathrm{Na}$ from weathering of cation exchange (Möller, 1990). A lower $\mathrm{Na}$ : Cl ratio $(<0.86)$ suggests inputs of terrestrial $\mathrm{Cl}$ or catchment retention of Na (Möller, 1990). The TN:TP $\left(\mu \mathrm{eq} \mathrm{L} \mathrm{L}^{-1}\right)$ ratio was used to assess if an aquatic system was either phosphorus $(\mathrm{P})$ or nitrogen $(\mathrm{N})$ limited, where ratios of TN:TP $<14$ (Downing and McCauley, 1992) indicate Nlimited, and ratios of TN:TP $>17$ (Sakamoto, 1966) indicate P-limited sites.

\section{Statistics}

All statistical analysis was preformed using $\mathrm{R}$ (version 3.3.2). Variables were tested for normality (lilliefor test from the package nortest), homogeneity of variance (Levene's test from the package car), and linearity (quantile-quantile plots from the package stats) prior to statistical analysis. However, due to the consistent nonnormal distribution among variables (found by testing for normality, homogeneity of variance, and linearity), nonparametric statistical tests were used. Percent coefficient of variation $(\% \mathrm{CV})$ was calculated following Canchola et al. (2017) and was performed on log transformed data. Correlation between physical and chemical variables was determined using the spearman's rank correlation $\left(r_{s}\right)$ from the package Hmisc. To determine if there were statistically different concentrations between regions (bedrock geology, ecoregion, and geographical region), the Kruskal-Wallis rank sum test (from the package stats) was used with a Dunn's post hoc test (Bonferroni adjustment; from the package dunn.test). Principal Component Analysis (PCA) was performed with log transformed variables, with the R packages ggbiplot and

Tab. 3. Summary of sampling sites per region with sampling year.

\begin{tabular}{|c|c|c|}
\hline Region & Site count & Years sampled \\
\hline Axel Heiberg Is. & 47 & $1995 / 1996 / 1998$ \\
\hline Baffin Is. & 132 & $1980 / 1984 / 1985 / 1993 / 2015 / 2016$ \\
\hline Banks Is. & 45 & 2000 \\
\hline Bathurst Is. & 67 & $1992 / 1994 / 1997 / 1998 / 1999 / 2000 / 2001 / 2002 / 2005$ \\
\hline Bylot Is. & 47 & $2005 / 2008$ \\
\hline Coats Is. & 10 & 2016 \\
\hline Cornwallis Is. & 47 & $1980 / 1992 / 1993$ \\
\hline Crozier Is. & 2 & 2008 \\
\hline Devon Is. & 66 & $1980 / 1994 / 1996 / 2000 / 2004 / 2005 / 2006 / 2006 / 2007$ \\
\hline Ellef Ringnes Is. & 25 & 1996 \\
\hline Ellesmere Is. & 170 & 1979/1989/1990/1992/1995/1996/1997/1998/1999/2001/2003/2007/2008 \\
\hline King William Is. & 4 & 1982 \\
\hline Little Cornwallis Is. & 1 & 1981 \\
\hline Melville Is. & 49 & $1992 / 2003 / 2004$ \\
\hline Mainland Northwest Territories & 153 & $1990 / 1991 / 1993 / 2015$ \\
\hline Mainland Nunavut & 190 & $1982 / 1983 / 1991 / 1999 / 2004 / 2006 / 2007 / 2008 / 2009 / 2010$ \\
\hline Prince Charles Is. & 5 & $1985 / 2016$ \\
\hline Prince of Wales Is. & 5 & $1994 / 1995$ \\
\hline Prince Patrick Is. & 35 & 1999 \\
\hline Somerset Is. & 13 & 1980/1989/1990/1991/1993/1994/1995/1996 \\
\hline Southampton Is. & 37 & $1983 / 2001 / 2002$ \\
\hline Victoria Is. & 88 & $1982 / 1997 / 2000 / 2004$ \\
\hline Yukon & 64 & $1990 / 1996 / 2000 / 2002$ \\
\hline Grand total & 1300 & Range: 1979-2016 \\
\hline
\end{tabular}


ggfortify to determine possible relationships, potential drivers of hydrochemistry, and the variability within the dataset. For the PCA, a subset of variables (Latitude, Longitude, elevation (Elev), distance to coast (DistC), area, $\mathrm{pH}$, Cond, $\mathrm{Ca}, \mathrm{K}, \mathrm{Mg}, \mathrm{Na}, \mathrm{SO}_{4}, \mathrm{Cl}, \mathrm{DOC}, \mathrm{DIC}, \mathrm{TN}$, $\mathrm{TP}, \mathrm{Al}, \mathrm{Fe}$, and $\mathrm{Mn}$ ) were included. These variables were only available for 613 sites (see Supporting Information F3), which excluded all sites situated in the NWF ecoregion. Thus, PCA results only pertain to sites within the $\mathrm{AC}, \mathrm{TU}$, and TA ecoregions.

\section{RESULTS}

\section{Water chemistry dataset}

A dataset of 1300 sites with 26 physical and chemical parameters was used in this study (Tab. 2), for other parameters $(n=59)$, e.g., $\mathrm{NO}_{2}, \mathrm{TDN}$, As, etc., see Supporting Material T1). Not all 1300 sites had observations for all 26 chemical and physical parameters, as such, summary observations reported as percentages refer to the total observed count for the variables (shown in Tab. 2). Only percentages reported for location, elevation, distance to coast, geology, ecoregion, and region of the Canadian Arctic are in reference to the 1300 sites. For example, $14.5 \%(n=127)$ of sites had an area $>100 \mathrm{ha}$, this means that for all sites with observations of area $(n=877$; Tab. 2$), 14.5 \%(n=127)$ had a lake area $>100$ ha. Similarly, $82.0 \%(n=1028)$ of sites had a $\mathrm{pH}>7$ (1028 of total sites with observations for $\mathrm{pH}$, i.e., 1253 sites; Tab. 2).

\section{Physical characteristics}

Most sites were on mainland Nunavut $(n=190)$, Ellesmere Is. $(\mathrm{n}=70)$, and mainland Northwest Territories $(\mathrm{n}=153)$ (Fig. 1; Tab. 3). Islands with the least number of sites were Little Cornwallis Is. ( $\mathrm{n}=1$; Hamilton et al., 2001), Crozier Is. ( $\mathrm{n}=2$; Michelutti et al., 2010), and King William Is. ( $\mathrm{n}=4$; Hamilton et al., 2010) (Fig. 1). The study sites were primarily located on remote and underdeveloped areas (Fig. 1). However, some sites were located near to population centers (Bunbury and Gajewski, 2002; Michelutti et al., 2007a; Hamilton et al., 2010; Medeiros et al., 2012; Liang and Aherne, 2019), research stations (Antoniades et al., 2003; Antoniades et al., 2010; Stewart and Lamoureux, 2011), within National Parks (Lim et al., 2005; Liang and Aherne, 2019; Côté et al., 2010, Hadley et al., 2013; Keatley et al., 2007; Hamilton et al., 2010), and along roadways (Moser et al., 1993; Bunbury and Gajewski, 2002; Pienitz et al., 1997a).

Approximately $66.5 \%(\mathrm{n}=864)$ of all sites were on sedimentary (SED) geology, 26.4\% $(n=343)$ were on igneous (IGN) geology, and $6.2 \%(\mathrm{n}=80)$ on supracrustal (SUP) geology (Fig. 2 Top; Tab. 4). Thirteen sites were on unclassified (UNC) geology (1.0\%; Fig. 2; Tab. 4) and were located on Somerset $(n=4)$, Bathurst Is. $(n=1)$, Yukon $(n=4)$, Devon Is. $(n=1)$, and Ellesmere Is. $(n=3)$. The UNC geology type consists primarily of metamorphic rock of granite gneiss, tonalite gneiss, granodiorite, paragneiss lithology (Harris et al., 2012). Within the four ecoregions, most sites $(84.8 \%, \mathrm{n}=1102)$ were located within the TU, which covers most of the Arctic Archipelago, mainland Nunavut, northern section of mainland Northwest Territories and Quebec (Fig. 2 Bottom; Tab. 5). This was followed by the TA at $9.1 \%$ $(\mathrm{n}=118), \mathrm{NWF}$ at $4.3 \%(\mathrm{n}=56)$, and lastly, the AC ecoregion at $1.8 \%(\mathrm{n}=24)$. Although most sites were situated within the SED geology and TU ecoregion types, in general sites were spatially distributed across the entire study area (see Supporting Material F4, F5, F6, and F7).

Most sites were situated at low elevations $(66.5 \%$, $\mathrm{n}=865,<200 \mathrm{~m}$ asl; Fig. 3 Top) and close to the coast $(72.5 \%, \mathrm{n}=938,0-50 \mathrm{~km}$; Fig. 3 Middle), indicative of the geographic distribution of lakes and ponds in the Arctic. Using the available data for lake depth (only 680 sites with this observation) and area (only 877 observations), $85.4 \%$ of sites ( $\mathrm{n}=581$; Fig. 3 Bottom) were classified as
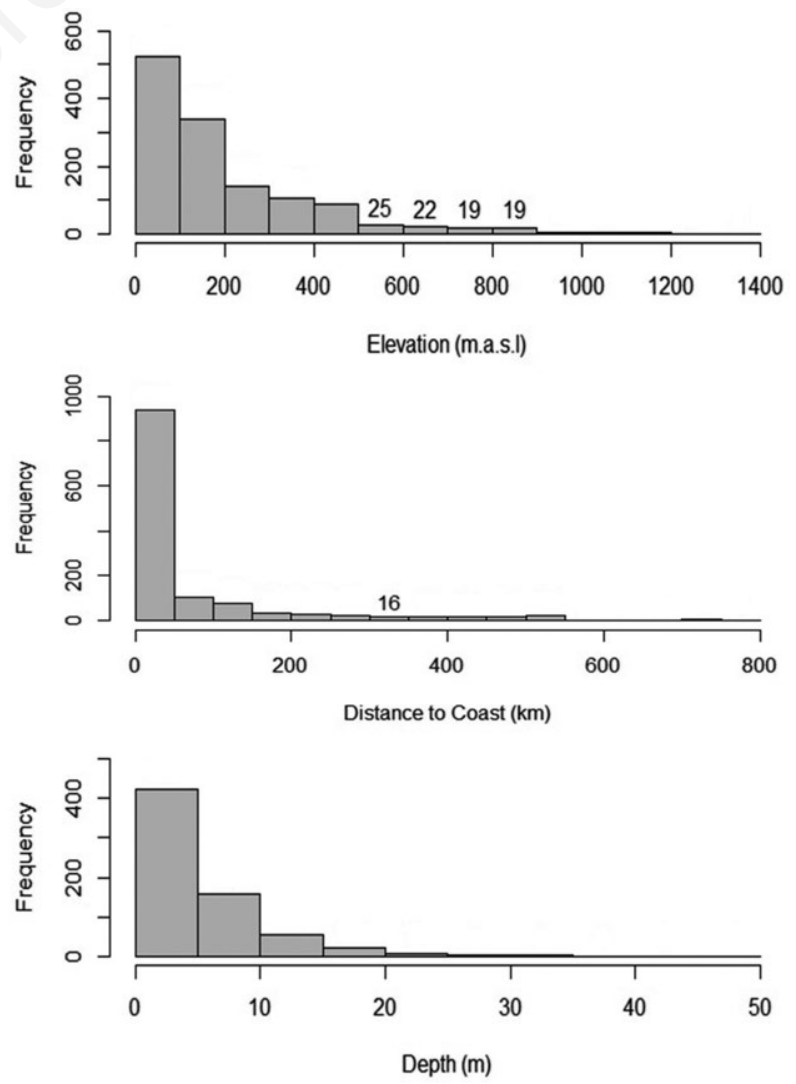

Fig. 3. Frequency distribution (histogram) of site characteristics: elevation (top), distance to coast (middle), and depth (bottom). 
shallow ( $\leq 10 \mathrm{~m}$; Hamilton et al., 2001), with only $31.6 \%$ $(\mathrm{n}=215)$ further classified as ponds $(\leq 2 \mathrm{~m}$; Lim et al., $2001)$, and $58.0 \%(\mathrm{n}=509)$ as small ( $\leq 10 \mathrm{ha}$; Hamilton et al., 2001).

\section{Water $\mathrm{pH}$ and conductivity}

Most sites $(82.0 \%, \mathrm{n}=1028)$ had $\mathrm{pH}>7$ (Tab. 2), with a median $\mathrm{pH}$ of 7.9 and a mean $=6.0(\mathrm{n}=253)$. By region, the lowest median $\mathrm{pH}$ values were observed in: Bylot Is. $=6.5$, Ellef Ringnes Is. $=6.8$, and Baffin Is. $=6.9$, while regions with the highest median $\mathrm{pH}$ values were Cornwallis Is. $=8.6$, Prince of Wales Is 8.4, and Yukon $=$ 8.4 (Tab. 6). Median surface water $\mathrm{pH}$ values by geology type were: $\mathrm{IGN}=7.3, \mathrm{SED}=8.1, \mathrm{SUP}=8.1$, and $\mathrm{UNC}=$ 8.1 (Tab. 4).

A significant positive correlation $(\mathrm{P}<0.01)$ was observed between $\mathrm{pH}$ and $\mathrm{Ca}\left(r_{s}=0.61\right), \mathrm{Mg}\left(r_{s}=0.59\right)$, and DIC $\left(r_{s}=0.64\right)$ (Fig. 4), which suggests that underlying bedrock and soils with carbonate content predominantly influence $\mathrm{pH}$ in Arctic surface waters. Water $\mathrm{pH}$ was found to be significantly (P 0.001) different between IGN and SED, and IGN and SUP geology (Fig. 5 Left middle; Tab. 7) and significantly different among ecoregions; NWF and AC, NWF and TA, NWF and TU, and TA and TU (Tab. 7). In addition, $\mathrm{pH}$ was found to be highest for the NWF ecoregion (8.37; Tab. 5) and lowest for the TA ecoregion (7.50).

Median conductivity was $97.4 \mu \mathrm{S} \mathrm{cm}-1$ but it varied widely from 1.46 to $13,200 \mu \mathrm{S} \mathrm{cm}^{-1}(\mathrm{CV}=263 \%$; Tab. $2)$; although the majority of sites $(75.5 \%, n=933)$ had values below $200 \mu \mathrm{S} \mathrm{cm}^{-1}$. Median conductivity by region was lowest for Bylot Is. $=15.9 \mu \mathrm{S} \mathrm{cm} \mathrm{cm}^{-1}$, Northwest Territories $=48.0 \mu \mathrm{S} \mathrm{cm}^{-1}$, and Baffin Is. $=50.8 \mu \mathrm{S} \mathrm{cm}^{-1}$, while higher values were found for Yukon $=305 \mu \mathrm{S} \mathrm{cm}^{-}$ ${ }^{1}$, Ellef Ringnes Is. $=228 \mu \mathrm{S} \mathrm{cm}^{-1}$, and Southampton Is. $=$ $222 \mu \mathrm{S} \mathrm{cm} \mathrm{cm}^{-1}$ (Tab. 6). Among bedrock geology,

Tab. 4. Median (mean) values and site count for selected water chemistry variables and ratios by bedrock geology: sedimentary (SED), igneous (IGN), supracrustal (SUP), and unclassified (UNC).

\begin{tabular}{|c|c|c|c|c|c|}
\hline \multirow[b]{2}{*}{ Variable } & \multirow[b]{2}{*}{ Unit } & \multicolumn{4}{|c|}{ Geology } \\
\hline & & IGN & SED & SUP & UNC \\
\hline Count & & 343 & 864 & 80 & 13 \\
\hline Elev & $\mathrm{m}$ asl & $178(230)$ & $117(163)$ & $365(406)$ & $240(383)$ \\
\hline DistC & $\mathrm{km}$ & $19.3(102)$ & $10.5(54.5)$ & $101(90.0)$ & $7.00(72.7)$ \\
\hline Area & ha & $10.3(335)$ & $4.25(1508)$ & 30.9 (491) & $4.75(9.11)$ \\
\hline $\mathrm{pH}$ & & $7.31(7.32)$ & $8.06(7.91)$ & $8.08(7.74)$ & $8.06(7.84)$ \\
\hline Cond & $\mu \mathrm{S} \cdot \mathrm{cm}^{-1}$ & $40.0(66.8)$ & $132(232)$ & $98.2(181)$ & 87 (248) \\
\hline $\mathrm{Ca}$ & $\mathrm{mg} \cdot \mathrm{L}^{-1}$ & $4.11(7.72)$ & $20.8(26)$ & $13.4(17.3)$ & $16(20.2)$ \\
\hline $\mathrm{K}$ & $\mathrm{mg} \cdot \mathrm{L}^{-1}$ & $0.40(0.69)$ & $0.60(1.95)$ & $1.17(1.92)$ & $0.60(2.3)$ \\
\hline $\mathrm{Mg}$ & $\mathrm{mg} \cdot \mathrm{L}^{-1}$ & $0.93(1.99)$ & $5.4(10.3)$ & $3.13(11.5)$ & $5.9(21.5)$ \\
\hline $\mathrm{Na}$ & $\mathrm{mg} \cdot \mathrm{L}^{-1}$ & $0.63(3.34)$ & $2.22(16.7)$ & $2.77(5.87)$ & $2.2(3.02)$ \\
\hline $\mathrm{Cl}$ & $\mathrm{mg} \cdot \mathrm{L}^{-1}$ & $0.9(6.08)$ & $2.93(21.4)$ & $1.52(6.75)$ & $1.37(2.54)$ \\
\hline $\mathrm{SO}_{4}$ & $\mathrm{mg} \cdot \mathrm{L}^{-1}$ & $1.99(5.29)$ & $3.9(39.2)$ & $3.9(12.0)$ & $2.9(55.2)$ \\
\hline $\mathrm{SiO}_{2}$ & $\mathrm{mg} \cdot \mathrm{L}^{-1}$ & $0.40(0.7)$ & $0.58(1.15)$ & $0.48(1.1)$ & $0.32(0.55)$ \\
\hline DOC & $\mathrm{mg} \cdot \mathrm{L}^{-1}$ & $2.90(4.74)$ & $3.80(6.10)$ & $3.90(6.04)$ & $2.20(3.12)$ \\
\hline POC & $\mathrm{mg} \cdot \mathrm{L}^{-1}$ & $0.34(0.54)$ & $0.42(0.57)$ & $0.29(0.37$ & N/A \\
\hline DIC & $\mathrm{mg} \cdot \mathrm{L}^{-1}$ & $3.7(5.27)$ & $15.9(17.1)$ & $5.95(10.1)$ & $5.00(7.17)$ \\
\hline $\mathrm{NH}_{3} *$ & $\mu \mathrm{g} \cdot \mathrm{L}^{-1}$ & $18.7(33.1)$ & $11(20.8)$ & $23(29.8)$ & $11(13.4)$ \\
\hline TKN* & $\mu \mathrm{g} \cdot \mathrm{L}^{-1}$ & $176(320)$ & $281(386)$ & $290(445)$ & $230(211)$ \\
\hline $\mathrm{TN}^{*}$ & $\mu \mathrm{g} \cdot \mathrm{L}^{-1}$ & $211(289)$ & $376(486)$ & $323(331)$ & $140(190)$ \\
\hline TP* & $\mu \mathrm{g} \cdot \mathrm{L}^{-1}$ & $6.00(8.11)$ & $7.40(12.5)$ & $7.70(10.4)$ & $7.71(7.32)$ \\
\hline $\mathrm{Al}$ & $\mu \mathrm{g} \cdot \mathrm{L}^{-1}$ & $12.8(30.8)$ & $17.7(150)$ & $29(34.6)$ & $16(28.8)$ \\
\hline $\mathrm{Ba}$ & $\mu \mathrm{g} \cdot \mathrm{L}^{-1}$ & $4(5.96)$ & $7.89(16.6)$ & $18.7(27.4)$ & $3.3(14.4)$ \\
\hline $\mathrm{Fe}$ & $\mu \mathrm{g} \cdot \mathrm{L}^{-1}$ & $47.7(147)$ & $49.4(226)$ & $31.2(81.5)$ & $47(44.1)$ \\
\hline $\mathrm{Mn}$ & $\mu g \cdot \mathrm{L}^{-1}$ & $6.57(523)$ & $4.6(575)$ & $7.35(15.2)$ & 8.95 (113) \\
\hline $\mathrm{Sr}$ & $\mu \mathrm{g} \cdot \mathrm{L}^{-1}$ & $14.5(22.2)$ & $30.1(86.7)$ & $116(125)$ & $28.0(121)$ \\
\hline TN:TP & Ratio & $207.8(248.3)$ & $245.2(319.5)$ & $229.4(229.3)$ & $129(172.3)$ \\
\hline $\mathrm{Na}: \mathrm{Cl}$ & Ratio & $1.03(1.52)$ & $0.96(2.15)$ & $1.39(3.59)$ & $0.96(2.26)$ \\
\hline
\end{tabular}


conductivity was higher for SED $=132.0 \mu \mathrm{S} \mathrm{cm}^{-1}$, SUP $=$ $98.2 \mu \mathrm{S} \mathrm{cm}^{-1}$, and $\mathrm{UNC}=87.0 \mu \mathrm{S} \mathrm{cm}^{-1}$, compared with IGN $=40.0 \mu \mathrm{S} \mathrm{cm}^{-1}$ (Tab. 4). Similar to $\mathrm{pH}$, conductivity was significantly different $(\mathrm{P}<0.001)$ between IGN and the other geology types (Fig. 5 Left Top; Tab. 7). Conductivity was more strongly correlated with $\mathrm{Ca}\left(r_{s}=\right.$ $0.89), \mathrm{Mg}\left(r_{s}=0.88\right)$ and DIC $\left(r_{s}=0.80\right)$, than $\mathrm{Na}\left(r_{s}=\right.$ $0.69)$ and $\mathrm{Cl}\left(r_{s}=0.60\right)$ (all with $\mathrm{P}<0.01$; Fig. 4) suggesting that geology had a greater impact on conductivity than sea-salt aerosols (as $\mathrm{Na}$ and $\mathrm{Cl}$ are markers of sea-salts).

\section{Major cations and anions}

The spatial coverage of sites with observations for selected major cations $(\mathrm{Ca}, \mathrm{Mg}, \mathrm{Na}, \mathrm{K})$ and anions $(\mathrm{Cl}$, $\mathrm{SO}_{4}$, DIC as a measure of bicarbonate and carbonate) was representative of the entire study region (see Supporting Material F4 and F5); 1290 (99.2\%) and 1255
$(96.5 \%)$ sites had observations of either one or more cation and anion, respectively. The median concentration for each base cation $\left(\mathrm{Ca}=14.6 \mathrm{mg} \mathrm{L}^{-1}, \mathrm{~K}=0.57 \mathrm{mg} \mathrm{L}^{-}\right.$ ${ }^{1}, \mathrm{Mg}=3.70 \mathrm{mg} \mathrm{L}^{-1}$ and $\mathrm{Na}=1.65 \mathrm{mg} \mathrm{L}^{-1}$; Tab. 2) was within the lower range of inland freshwater systems in Canada (McNeely et al., 1979). The highest median Ca concentration $\left(20.8 \mathrm{mg} \mathrm{L}^{-1}\right)$ was associated with the SED geology type, and the highest $\mathrm{Mg}$ concentration (5.90 $\mathrm{mg} \mathrm{L}^{-1}$ ) with UNC (Tab. 4). For both $\mathrm{K}$ and $\mathrm{Na}$, the highest median concentrations $\left(\mathrm{K}=1.17 \mathrm{mg} \mathrm{L}^{-1}, \mathrm{Na}\right.$ $=2.77 \mathrm{mg} \mathrm{L}^{-1}$ ) were observed on the SUP geology (Tab. 4). Sites with lower median cation concentrations were underlain by IGN geology; $\mathrm{Ca}=4.11 \mathrm{mg} \mathrm{L}^{-1}, \mathrm{~K}=0.4$ $\mathrm{mg} \mathrm{L}^{-1}, \mathrm{Mg}=0.9 \mathrm{mg} \mathrm{L}^{-1}$, and $\mathrm{Na}=0.63 \mathrm{mg} \mathrm{L}^{-1}$ (Tab. 4). Significant differences $(p<0.001)$ for each base cation were found between IGN and SED, and IGN and SUP geology (Tab. 7).

For anions, the median concentrations were $2.05 \mathrm{mg}$

Tab. 5. Median (mean) values and site count for selected water chemistry variables and ratios by ecoregion type: Arctic Cordillera (AC), Northwestern Forested Mountains (NWF), Taiga (TA), and Tundra (TU).

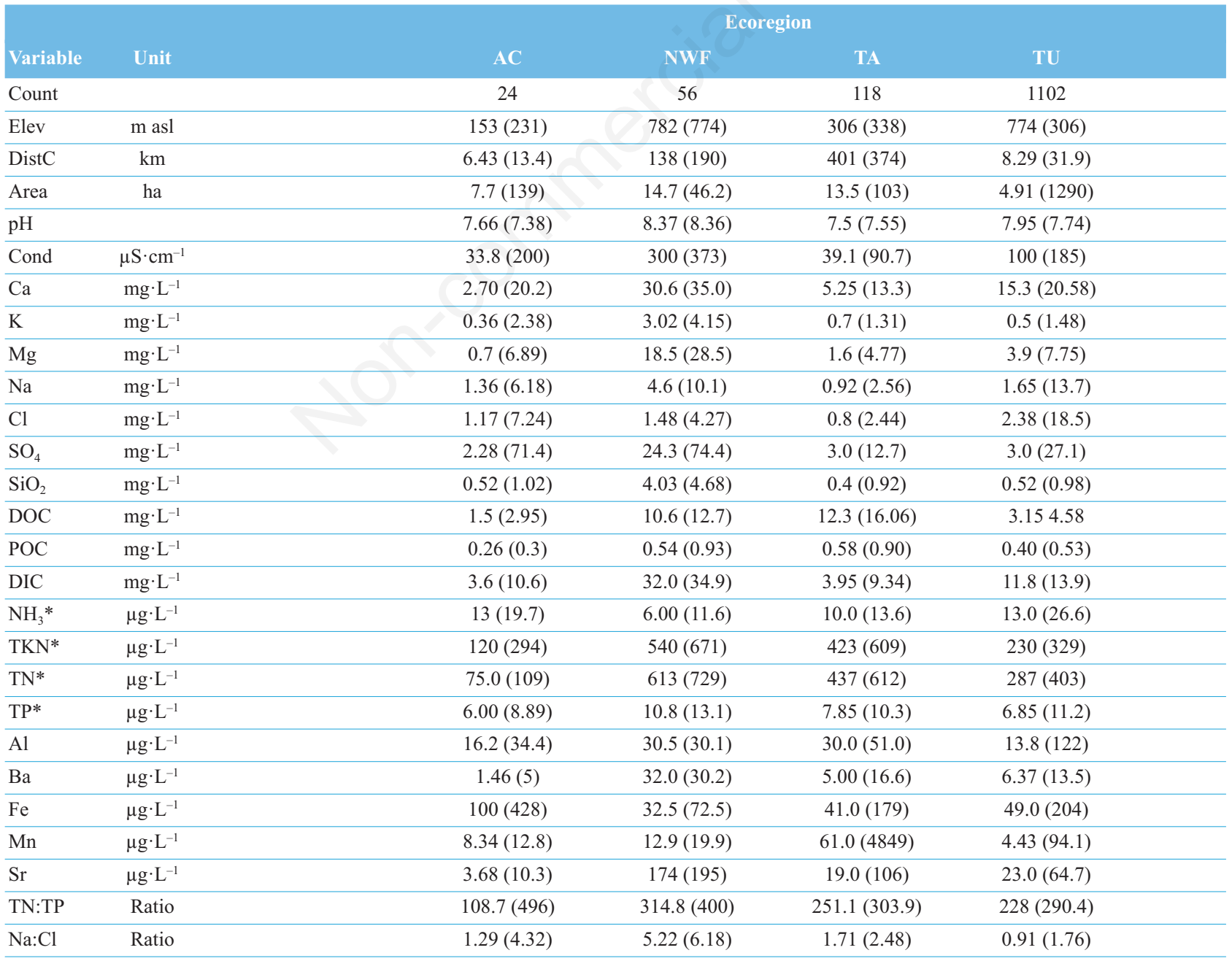


$\mathrm{L}^{-1}$ for $\mathrm{Cl}, 3.10 \mathrm{mg} \mathrm{L}^{-1}$ for $\mathrm{SO}_{4}$, and $10.9 \mathrm{mg} \mathrm{L}^{-1}$ for DIC (Tab. 2). Median anion values were also within the lower range of inland freshwater systems in Canada (McNeely et al.,1979). The highest median anion concentrations were consistently associated with SED geology; $2.93 \mathrm{mg}$ $\mathrm{L}^{-1}$ for $\mathrm{Cl}, 3.90 \mathrm{mg} \mathrm{L}^{-1}$ for $\mathrm{SO}_{4}$, and $15.9 \mathrm{mg} \mathrm{L}^{-1}$ for $\mathrm{DIC}$, while lower medians were consistently found for IGN geology; $0.90 \mathrm{mg} \mathrm{L}^{-1}$ for $\mathrm{Cl}, 1.99 \mathrm{mg} \mathrm{L}^{-1}$ for $\mathrm{SO}_{4}$, and $3.7 \mathrm{mg} \mathrm{L}^{-1}$ for DIC (Tab. 4). A similar pattern was observed for cations and anions, where significant differences were found between IGN and SED geology (Tab. 7).

Surface water DIC was highly correlated with $\mathrm{Ca}$ and $\mathrm{Mg} ; r_{s}=0.87$ for $\mathrm{Ca}, r_{s}=0.81$ for $\mathrm{Mg}(\mathrm{P}<0.01$; Fig. 4$)$ further suggesting the influence of weathering from bedrock geology. The correlation between $\mathrm{Na}$ and $\mathrm{Cl}\left(r_{s}\right.$ $=0.85 ; \mathrm{P}<0.01$, Fig. 4) and elevation $\left(r_{s}=-0.62\right.$; $\mathrm{P}<0.01$; Fig. 4) suggests a sea-salt influence, which decrease with elevation (from coast). Generally, median concentrations were ranked in decreasing order

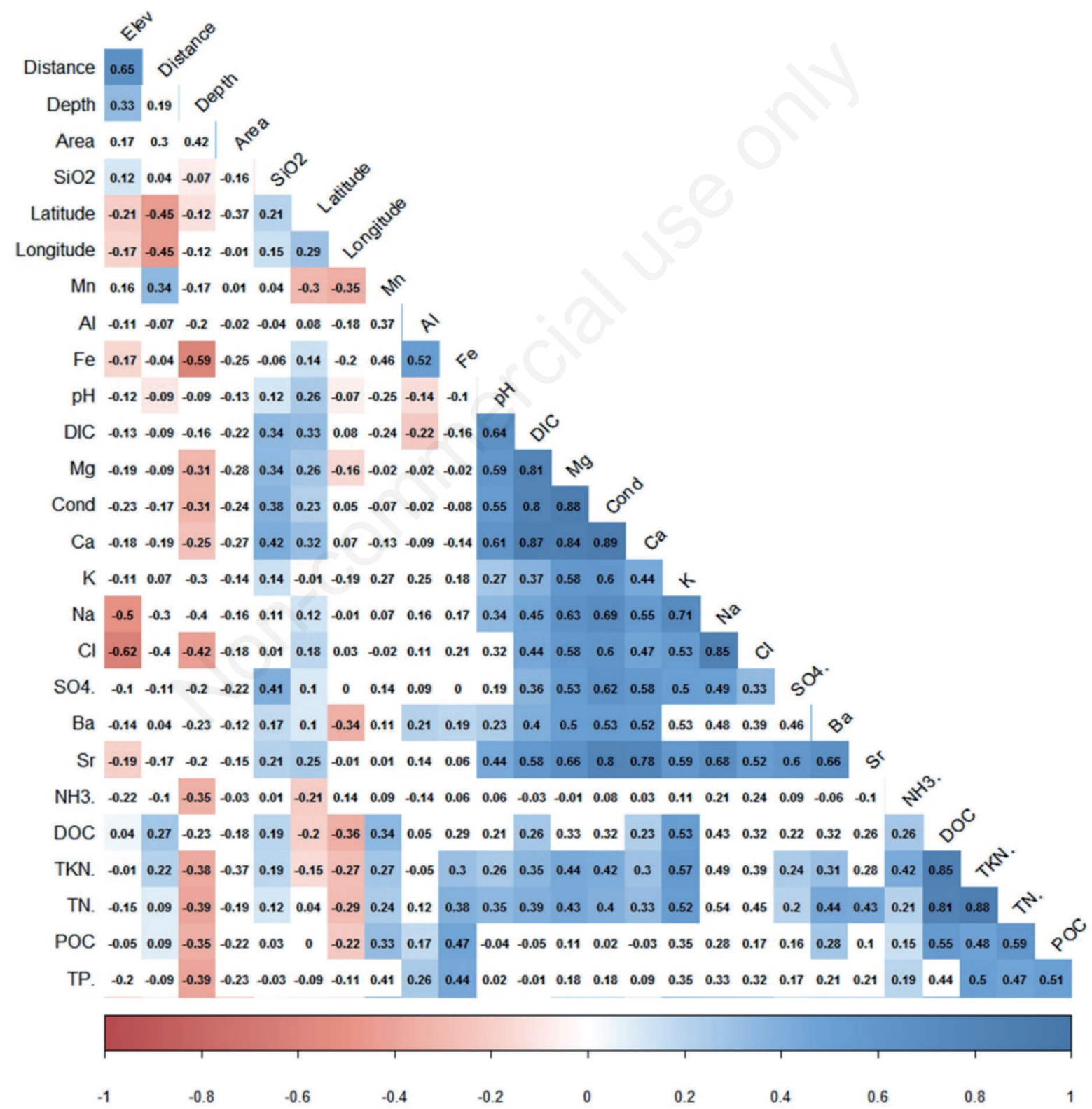

Fig. 4. Correlation matrix of selected physical and chemical variables showing Spearman's rank correlation coefficient. Significant $(\mathrm{P}<0.01)$ correlation coefficients are highlighted in colour. Note: the correlation matrix was based on pairwise complete observation, i.e., correlation between each pair of variables was computed using all complete pairs of observations for those variables. 
$\mathrm{Ca}>\mathrm{Mg}>\mathrm{Na}>\mathrm{Na}$ for cations and $\mathrm{DIC}>\mathrm{SO}_{4}>\mathrm{Cl}$ for anions (Tab. 2). Of the 1300 sites, 1251 had observations of $\mathrm{Na}$ and $\mathrm{Cl}$, where most sites $(60.6 \% ; \mathrm{n}=758)$ had $\mathrm{Na}: \mathrm{Cl}$ ratios $>0.86$; the remainder $(39.4 \% ; n=493)$ had $\mathrm{Na}: \mathrm{Cl}$ ratios $\leq 0.86$.

\section{Phosphorous, nitrogen and carbon}

The spatial coverage of sites with observations of selected nutrients (TP, TN, DOC) was also representative of the entire study region (Supporting Material F6), as all 1300 sites had observations of either one or more

Tab. 6. Median (mean) values and site count for selected water chemistry variables and ratios for each Arctic region.

\begin{tabular}{|c|c|c|c|c|c|c|}
\hline & & $\mathrm{m}$ asl & km & ha & & $\mu \mathrm{S} \cdot \mathrm{cm}^{-1}$ \\
\hline Region & Count & Elev & DistC & Area & pH & Cond \\
\hline Axel Heiberg Is. & 47 & $171(214)$ & $5.94(7.37)$ & $15.5(20.8)$ & $8.05(5.03)$ & $128(402)$ \\
\hline Baffin Is. & 132 & $139(153)$ & $5.62(12.1)$ & $4.85(6632)$ & $6.89(5.23)$ & $50.8(88.1)$ \\
\hline Banks Is. & 45 & $128(136)$ & $29.6(34.1)$ & $1.00(16.8)$ & $8.10(7.90)$ & 109 (182) \\
\hline Bathurst Is. & 67 & $61(94.3)$ & $5.27(7.72)$ & $19.6(34.0)$ & $8.20(7.85)$ & $131(127)$ \\
\hline Bylot Is. & 47 & $179(237)$ & $4.91(7.22)$ & $5.86(25.7)$ & $6.50(6.50)$ & $15.9(34.8)$ \\
\hline Coats Is. & 10 & $41.5(41.3)$ & $7.81(7.81)$ & & 20 & $103(111)$ \\
\hline Cornwallis Is. & 47 & $64(80.6)$ & $2.00(4.79)$ & $18.1(32.9)$ & $8.60(8.24)$ & $127(451)$ \\
\hline Devon Is. & 66 & $81(89.5)$ & $4.76(7.87)$ & $0.72(19.1)$ & $8.28(8.00)$ & 99.5 (121) \\
\hline Ellef Ringnes Is. & 25 & $43(38.4)$ & $1.51(1.41)$ & $0.06(1.32)$ & $6.80(6.21)$ & $228(405)$ \\
\hline Ellesmere Is. & 170 & $170(224)$ & $11.9(17.8)$ & $1.84(810)$ & $8.20(7.65)$ & $216(356)$ \\
\hline Melville Is. & 49 & $76.2(125)$ & $3.82(4.98)$ & $2.06(15.0)$ & $8.00(7.81)$ & $56.0(149)$ \\
\hline Mainland Northwest Territories & 153 & $311(289)$ & $312(315)$ & $18.9(81.1)$ & $7.5(7.02)$ & $48.0(91.2)$ \\
\hline Mainland Nunavut & 190 & $111(180)$ & $79.1(86.3)$ & $15.0(1567)$ & $7.55(6.50)$ & $51.0(75.7)$ \\
\hline Prince Charles Is. & 5 & $10(8.64)$ & $2.48(2.58)$ & $2500(2500)$ & $7.98(7.98)$ & $76.2(98.6)$ \\
\hline Prince of Wales Is. & 5 & $122(110)$ & $19.0(19.4)$ & $0.90(172)$ & $8.40(8.18)$ & $65.0(114)$ \\
\hline Prince Patrick Is. & 35 & $8.00(21.4)$ & $1.17(1.20)$ & $0.05(1.43)$ & $7.80(7.67)$ & $75.0(115)$ \\
\hline Somerset Is. & 13 & $170(156)$ & $6.54(9.45)$ & $11.0(12.36)$ & $7.90(7.81)$ & $60.0(81)$ \\
\hline Southampton Is. & 37 & $40.0(65.1)$ & $6.59(13.6)$ & $16.0(259)$ & $7.96(7.83)$ & $222(251)$ \\
\hline Victoria Is. & 88 & $139(159)$ & $22.6(37.5)$ & $11.1(32.4)$ & $7.80(7.74)$ & $140(156)$ \\
\hline \multirow[t]{2}{*}{ Yukon } & 62 & $787(794)$ & $152(211)$ & $14.8(45.1)$ & $8.37(7.97)$ & $305(343)$ \\
\hline & $\mathrm{mg} \cdot \mathrm{L}^{-1}$ & $\mathbf{m g} \cdot \mathbf{L}^{-1}$ & $\mathbf{m g} \cdot \mathbf{L}^{-1}$ & $\mathbf{m g} \cdot \mathbf{L}^{-1}$ & $\mathbf{m g} \cdot \mathbf{L}^{-1}$ & $\mathbf{m g} \cdot \mathbf{L}^{-1}$ \\
\hline Region & $\mathrm{Ca}$ & K & $\mathrm{Mg}$ & $\mathrm{Na}$ & $\mathrm{Cl}$ & $\mathrm{SO}_{4}$ \\
\hline Axel Heiberg Is. & $17.8(32.1)$ & $1.10(4.22)$ & $4.70(14.0)$ & $3.40(53.6)$ & $2.16(80.6)$ & $9.30(62.9)$ \\
\hline Baffin Is. & $5.75(8.64)$ & $0.18(0.67)$ & $0.83(1.57)$ & $0.59(3.37)$ & $0.98(6.74)$ & $2.91(8.43)$ \\
\hline Banks Is. & $17.2(19.2)$ & $0.60(1.38)$ & $9.10(12.6)$ & $1.20(15.6)$ & $2.86(29.4)$ & $9.30(15.0)$ \\
\hline Bathurst Is. & $24.7(22.9)$ & $0.30(0.55)$ & $4.00(4.52)$ & $1.78(4.50)$ & $2.83(7.69)$ & $3.50(5.05)$ \\
\hline Bylot Is. & $1.77(3.33)$ & $0.53(0.68)$ & $1.29(1.64)$ & $1.71(2.18)$ & $1.42(2.37)$ & $0.70(2.12)$ \\
\hline Coats Is. & $19.4(22.6)$ & $0.50(0.62)$ & $5.90(6.62)$ & $13.4(13.1)$ & $25.3(33.7)$ & $2.61(4.00)$ \\
\hline Cornwallis Is. & $26.0(23.9)$ & $0.30(0.60)$ & $5.15(5.62)$ & $2.47(8.81)$ & $4.30(11.4)$ & $1.55(5.00)$ \\
\hline Devon Is. & $24.5(25.1)$ & $0.20(0.26)$ & $5.45(6.01)$ & $1.20(1.85)$ & $2.47(3.82)$ & 2.50 (13.9) \\
\hline Ellef Ringnes Is. & $21.3(49.1)$ & $2.10(4.26)$ & $12.4(35.6)$ & $17.0(71.6)$ & $7.30(47.4)$ & $131(303)$ \\
\hline Ellesmere Is. & $31.0(42.3)$ & $1.00(3.64)$ & $7.57(15.5)$ & $3.25(27.1)$ & $2.74(29.8)$ & $7.90(76.8)$ \\
\hline Melville Is. & $5.8 .0(14.9)$ & $0.85(1.50)$ & $3.00(8.10)$ & $2.00(18.1)$ & $4.12(35.4)$ & $1.80(13.1)$ \\
\hline Mainland Northwest Territories & $5.10(12.7)$ & $0.77(1.25)$ & $1.10(4.30)$ & $0.90(2.97)$ & $0.80(3.75)$ & $2.70(10.9)$ \\
\hline Mainland Nunavut & $4.08(6.40)$ & $0.50(0.78)$ & $1.32(2.43)$ & $1.12(5.67)$ & $1.77(10.8)$ & $1.71(2.69)$ \\
\hline Prince Charles Is. & $17.0(17.3)$ & $0.54(0.60)$ & $3.23(3.20)$ & $1.52(5.35)$ & $1.32(7.47)$ & $0.90(2.57)$ \\
\hline Prince of Wales Is. & $26.0(27.0)$ & $0.50(0.48)$ & $10.3(10.6)$ & $1.70(1.54)$ & $3.30(3.03)$ & $6.70(9.52)$ \\
\hline Prince Patrick Is. & $12.1(13.2)$ & $0.80(1.06)$ & $3.30(5.15)$ & $4.10(12.9)$ & $9.32(25.0)$ & $4.00(7.7)$ \\
\hline Somerset Is. & $10.0(13.4)$ & $0.24(0.24)$ & $3.60(3.97)$ & $0.71(1.21)$ & $1.31(2.18)$ & $1.80(3.46)$ \\
\hline Southampton Is. & $31.9(29.8)$ & $0.58(1.32)$ & $6.10(6.87)$ & $6.46(19.2)$ & $3.53(8.60)$ & $13.2(39.6)$ \\
\hline Victoria Is. & $22.5(21.3)$ & $0.34(0.45)$ & $9.44(10.9)$ & $0.75(1.75)$ & $1.70(4.08)$ & $2.04(4.45)$ \\
\hline Yukon & $30.0(33.1)$ & $2.60(3.78)$ & $18.5(28.5)$ & $4.04(9.30)$ & $1.38(3.91)$ & $20.5(68.0)$ \\
\hline
\end{tabular}


nutrients. Total phosphorous (TP) ranged greatly from 0.04 to $761.10 \mu \mathrm{g} \mathrm{L}^{-1}$, with a median of $7.05 \mu \mathrm{g} \mathrm{L}^{-1}$ (mean $=11.14 \mu \mathrm{g} \mathrm{L}^{-1}, \mathrm{n}=1248 ;$ Tab. 2). A large portion of sites were classified as oligotrophic $(45.6 \%, n=569)$, with concentrations between 4-10 $\mu \mathrm{g} \mathrm{L} \mathrm{L}^{-1}$ of TP (CCME, 2004).
This was followed by sites classified as ultra-oligotrophic (24.8\%, $\mathrm{n}=310)$, mesotrophic $(20.9 \%, \mathrm{n}=261)$, mesoeutrophic $(5.5 \%, \mathrm{n}=69)$, eutrophic $(2.5 \%, \mathrm{n}=31)$, and hyper-eutrophic $(0.7 \%, \mathrm{n}=8)$. Median TP concentrations per region (Tab. 6) were lowest on Axel Heiberg Is. (3.15

Tab. 6. Continued from previous page.

\begin{tabular}{|c|c|c|c|c|c|c|}
\hline & $\mathrm{mg} \cdot \mathrm{L}^{-1}$ & $\mathrm{mg} \cdot \mathrm{L}^{-1}$ & $\mathrm{mg} \cdot \mathrm{L}^{-1}$ & $\mathrm{mg} \cdot \mathrm{L}^{-1}$ & $\mu g \cdot L^{-1}$ & $\mu g \cdot L^{-1}$ \\
\hline Region & $\mathrm{SiO}_{2}$ & DOC & POC & DIC & $\mathrm{NH}_{3} *$ & $\mathrm{TKN} *$ \\
\hline Axel Heiberg Is. & $1.17(1.74)$ & $2.8(4.98)$ & $11.6(13.9)$ & $5.00(10.67)$ & $5.00(10.7)$ & $197(385)$ \\
\hline Baffin Is. & $1.10(1.30)$ & $1.91(2.17)$ & $3.99(5.60)$ & $21.0(35.8)$ & $21.0(35.8)$ & $92.5(150)$ \\
\hline Banks Is. & $1.15(1.34)$ & $5.60(6.2)$ & $15.9(18.0)$ & & & $377(438)$ \\
\hline Bathurst Is. & $0.28(0.59)$ & $3.20(3.95)$ & $16.3(15.5)$ & $7.00(9.17)$ & $7.00(9.17)$ & $162(271)$ \\
\hline Bylot Is. & $1.16(1.44)$ & $6.10(5.23)$ & $0.90(1.03)$ & $10.0(14.9)$ & $10.9(14.9)$ & $300(333)$ \\
\hline Coats Is. & & $6.11(5.97)$ & $7.92(9.20)$ & $12.3(46.6)$ & $12.2(46.6)$ & \\
\hline Cornwallis Is. & $0.40(0.42)$ & $1.80(2.26)$ & $19.1(16.8)$ & $8.50(7.98)$ & $8.59(7.98)$ & $80.0(164)$ \\
\hline Devon Is. & $0.35(0.51)$ & $1.72(2.64)$ & $17.2(16.3)$ & $7.10(8.52)$ & $7.19(8.52)$ & $83.5(116)$ \\
\hline Ellef Ringnes Is. & $1.18(1.42)$ & $1.90(2.08)$ & $2.40(6.22)$ & $5.00(17.3)$ & $5.00(17.3)$ & $147(148)$ \\
\hline Ellesmere Is. & $1.20(1.97)$ & $3.75(6.61)$ & $24.1(23.8)$ & $12.0(22.2)$ & $12.0(22.2)$ & $298(473)$ \\
\hline Melville Is. & $0.20(0.41)$ & $4.30(5.28)$ & $6.70(11.9)$ & $10.0(11.0)$ & $10.0(11.04)$ & $224(327)$ \\
\hline Mainland Northwest Territories & $0.40(0.81)$ & $9.8(12.9)$ & $3.95(9.08)$ & $9.00(27.7)$ & $9.00(27.7)$ & $348(489)$ \\
\hline Mainland Nunavut & $0.30(0.48)$ & $3.80(4.99)$ & $4.10(5.10)$ & $33.0(37.0)$ & $33.0(37.0)$ & $218(366)$ \\
\hline Prince Charles Is. & & $3.79(3.56)$ & $9.07(8.60)$ & $15.8(17.4)$ & $15.8(17.4)$ & $390(390)$ \\
\hline Prince of Wales Is. & $0.48(0.45)$ & $4.60(3.94)$ & $24.7(24.4)$ & $14.0(18.6)$ & $14.0(18.6)$ & $399(403)$ \\
\hline Prince Patrick Is. & $0.17(0.41)$ & $6.90(6.71)$ & $7.60(9.43)$ & $26.0(35.3)$ & $26.0(35.3)$ & $490(515)$ \\
\hline Somerset Is. & $0.14(0.22)$ & $0.78(1.17)$ & $9.35(9.91)$ & $8.00(11.9)$ & $8.00(11.9)$ & $100(117)$ \\
\hline Southampton Is. & $0.61(1.16)$ & $5.33(5.62)$ & $20.3(19.8)$ & & & $235(207)$ \\
\hline Victoria Is. & $0.80(0.92)$ & $2.20(2.71)$ & $21.3(20.5)$ & $13.0(17.57)$ & $13.0(17.6)$ & $230(258)$ \\
\hline \multirow[t]{2}{*}{ Yukon } & $2.42(3.84)$ & $10.6(12.5)$ & $19.3(27.9)$ & $6.50(11.5)$ & $6.50(11.5)$ & $520(640)$ \\
\hline & $\mu \mathrm{g} \cdot \mathrm{L}^{-1}$ & $\mu \mathrm{g} \cdot \mathrm{L}^{-1}$ & $\mu \mathrm{g} \cdot \mathbf{L}^{-1}$ & $\mu g \cdot L^{-1}$ & $\mu g \cdot L^{-1}$ & $\mu g \cdot L^{-1}$ \\
\hline Region & $\mathrm{TN}^{*}$ & $\mathrm{TP} *$ & Al & $\mathrm{Ba}$ & $\mathrm{Fe}$ & Mn \\
\hline Axel Heiberg Is. & $188(385.52)$ & $3.15(4.66)$ & $10(68.94)$ & $9.6(18.72)$ & $5(31.43)$ & $0.4(40.28)$ \\
\hline Baffin Is. & $89.17(104.55)$ & $8(11.72)$ & $8.53(217.55)$ & $2.51(3.67)$ & $27.35(123.71)$ & $4.44(9.6)$ \\
\hline Banks Is. & $425(502.69)$ & 9.55 (13.37) & $10(136.91)$ & $14.1(19.14)$ & $101(396.22)$ & $14.2(27.32)$ \\
\hline Bathurst Is. & $476.8(526.27)$ & $6.47(8.31)$ & $20(75.24)$ & $34.5(47.58)$ & $64.5(203.52)$ & $3(5.16)$ \\
\hline Bylot Is. & $255(303.29)$ & $7.8(9.33)$ & & & & \\
\hline Coats Is. & $438.34(516.9)$ & $23.69(24.76)$ & $6.4(7.82)$ & $3.31(3.37)$ & $19.6(21.33)$ & $8.19(8.59)$ \\
\hline Cornwallis Is. & $73.11(63.9)$ & $3.8(25.69)$ & $6.5(11.93)$ & $6.2(17.35)$ & $10(20.69)$ & $1.05(1.35)$ \\
\hline Devon Is. & $133.5(278.01)$ & $6.06(15.01)$ & $10(35.29)$ & $2.63(5.08)$ & $21(44.08)$ & $1.06(1.77)$ \\
\hline Ellef Ringnes Is. & $232(294.52)$ & $11.3(23.98)$ & $180(399.2)$ & $13.9(16.35)$ & $216(680.32)$ & $18(205.19)$ \\
\hline Ellesmere Is. & 477 (679.84) & $6.34(7.56)$ & $20(179.45)$ & $5.1(11.32)$ & 73.5 (295.7) & $5.5(11.3)$ \\
\hline Melville Is. & $191.5(191.5)$ & $11.2(15.39)$ & $55(329.08)$ & $5.4(8.39)$ & $150.5(468.5)$ & $5.45(7.55)$ \\
\hline Mainland Northwest Territories & $403(530.32)$ & $7.8(10.29)$ & $27.29(43.31)$ & $5(15.09)$ & $39.45(129.63)$ & $44(3843.76)$ \\
\hline Mainland Nunavut & $315(402.7)$ & $5.8(7.82)$ & $20.7(57.43)$ & $6.11(7.62)$ & $109(222.63)$ & $6.66(263.59)$ \\
\hline Prince Charles Is. & $432.21(401.81)$ & $14.75(15.76)$ & $5.18(7.41)$ & $1.27(1.27)$ & $11.78(13.2)$ & $9.3(7.22)$ \\
\hline Prince of Wales Is. & $174(305.33)$ & $4.25(5.18)$ & $40(39)$ & $13(15.34)$ & $59(52.4)$ & $2.1(1.94)$ \\
\hline Prince Patrick Is. & $591(616.34)$ & $9.6(12.45)$ & $30(117.89)$ & $12.7(15.82)$ & $267(724.43)$ & $5.6(18.49)$ \\
\hline Somerset Is. & $110.69(144.16)$ & $4.09(5.36)$ & $5.44(6.17)$ & $3.7(3.39)$ & $16(24.71)$ & $1.7(2.69)$ \\
\hline Southampton Is. & $605.9(715.56)$ & $4.7(22.63)$ & $12.35(20.96)$ & & $12.35(18.39)$ & \\
\hline Victoria Is. & $221(258.53)$ & $4.1(5.57)$ & $8.9(10.56)$ & $6.2(7.13)$ & $23.95(31.55)$ & $1.47(2.05)$ \\
\hline Yukon & $540(650.45)$ & $10.57(13.13)$ & $30.5(30.07)$ & $32(30.23)$ & $36.65(107.08)$ & $13.8(20.55)$ \\
\hline
\end{tabular}


Tab. 6. Continued from previous page.

\begin{tabular}{lccc} 
& $\mu g \cdot \mathrm{L}^{-1}$ & Ratio & Ratio \\
Region & $\mathrm{Sr}$ & $\mathrm{Na}: \mathrm{Cl}$ & $1.39(4.32)$ \\
\hline Axel Heiberg Is. & $48.2(198)$ & $375(593.8)$ & $0.99(1.24)$ \\
\hline Baffin Is. & $12.2(13.5)$ & $48.5(72.6)$ & $0.63(0.77)$ \\
\hline Banks Is. & $28.1(38.1)$ & $200.8(219.1)$ & $0.88(1.36)$ \\
\hline Bathurst Is. & $41.5(86.5)$ & $360.2(356.5)$ & $1.64(2.08)$ \\
\hline Bylot Is. & $26.0(28.9)$ & $170.1(180.9)$ & $0.77(0.8)$ \\
\hline Coats Is. & $44.4(56.2)$ & $96.7(101.6)$ & $0.87(5.87)$ \\
\hline Cornwallis Is. & $20.5(104)$ & $129.1(110.8)$ & $3.6(4.36)$ \\
\hline Devon Is. & $70.7(126)$ & $119.5(142.1)$ & $1.14(2.31)$ \\
\hline Ellef Ringnes Is. & $78.3(126)$ & $82.2(89.7)$ & $0.77(0.85)$ \\
\hline Ellesmere Is. & $16.0(49.9)$ & $324.8(396)$ & $1.49(2.14)$ \\
\hline Melville Is. & $12.0(92.1)$ & $116.6(116.6)$ & $0.96(1.25)$ \\
\hline Mainland Northwest Territories & $19.5(25.4)$ & $230.8(271.5)$ & $1.5(1.71)$ \\
\hline Mainland Nunavut & $12.7(15.3)$ & $237.9(253.2)$ & $0.79(0.78)$ \\
\hline Prince Charles Is. & $55.0(48.0)$ & $120.7(121.5)$ & $0.71(0.76)$ \\
\hline Prince of Wales Is. & $32.3(48.3)$ & $316.3(269.8)$ & $0.84(0.9)$ \\
\hline Prince Patrick Is. & $28.0(35.3)$ & $274.8(284.2)$ & $3.14(3.55)$ \\
\hline Somerset Is. & & $137.9(189.1)$ & $0.68(0.73)$ \\
\hline Southampton Is. & $16.1(18.3)$ & $588.2(585.3)$ & $5.13(6.19)$ \\
\hline Victoria Is. & $174(194)$ & $457.8(576.8)$ & $1.39(4.32)$ \\
\hline Yukon & & $294.5(344.8)$ & \\
\hline
\end{tabular}

Tab. 7. Significant differences estimated by Kruskal-Wallis rank sum test and Dunn's post-hoc test with Bonferroni adjustment for chemical variables among bedrock geology and ecoregion types indicated by: ${ }^{*} \mathrm{P}<0.05, * * \mathrm{P}<0.01, * * * \mathrm{P}<0.001$. Geology type: sedimentary (SED), igneous (IGN), supracrustal (SUP), and unclassified (UNC). Ecoregion type: Arctic Cordillera (AC), Tundra (TU), Taiga (TA), and Northwestern Forested Mountains (NWF).

\section{IGN-SED IGN-SUP IGN-UNC SED-SUP AC-NWF AC-TA AC-TU NWF-TA NWF-TU TA-TU}

\begin{tabular}{|c|c|c|c|c|c|c|c|c|c|c|}
\hline $\mathrm{pH}$ & $* * *$ & $* * *$ & $*$ & $\hat{1}$ & $* * *$ & & & $* * *$ & $* * *$ & $* * *$ \\
\hline Cond & $* * *$ & $* * *$ & $* * *$ & & $* * *$ & & & $* * *$ & $* * *$ & $* * *$ \\
\hline $\mathrm{Ca}$ & $* * *$ & $* * *$ & $* *$ & $*$ & $* * *$ & & $*$ & $* * *$ & $* * *$ & $* * *$ \\
\hline K & $* * *$ & $* * *$ & & $*$ & $* * *$ & & & $* * *$ & $* * *$ & $* * *$ \\
\hline $\mathrm{Mg}$ & $* * *$ & $* * *$ & $* * *$ & & $* * *$ & & $* * *$ & $* * *$ & $* * *$ & $* * *$ \\
\hline $\mathrm{Na}$ & $* * *$ & $* * *$ & & & $* *$ & & & $* * *$ & $* * *$ & $* *$ \\
\hline $\mathrm{Cl}$ & $* * *$ & & & $* *$ & & & & $*$ & $*$ & $* * *$ \\
\hline $\mathrm{SO}_{4}$ & $* * *$ & $* * *$ & & & $* * *$ & & & $* * *$ & $* * *$ & \\
\hline $\mathrm{SiO}_{2}$ & $* * *$ & & & & $*$ & & & $* *$ & $* *$ & \\
\hline $\mathrm{DOC}$ & $* *$ & & & & $* * *$ & $* * *$ & $*$ & & $* * *$ & $* * *$ \\
\hline DIC & $* * *$ & $* *$ & & $*$ & $* *$ & & & $* * *$ & $*$ & $* * *$ \\
\hline POC & $*$ & & & & $* * *$ & $* * *$ & & & $*$ & $* * *$ \\
\hline $\mathrm{NH}_{3} *$ & $* * *$ & & & & & & & & & $*$ \\
\hline $\mathrm{TN}^{*}$ & $* * *$ & & & & $* * *$ & $* * *$ & $* * *$ & & $* * *$ & $* * *$ \\
\hline TP* & $* * *$ & $* * *$ & & & $* *$ & & & $*$ & $* * *$ & \\
\hline $\mathrm{Al}$ & & $* *$ & & & & & & & & $*$ \\
\hline $\mathrm{Ba}$ & $* * *$ & $* * *$ & & $*$ & $* * *$ & $*$ & $*$ & $* * *$ & $* * *$ & \\
\hline $\mathrm{Fe}$ & & & & & $*$ & & & & & \\
\hline $\mathrm{Mn}$ & $* *$ & & & & & $*$ & & & $* * *$ & $* * *$ \\
\hline $\mathrm{Sr}$ & $* * *$ & $* * *$ & $*$ & $* * *$ & $* * *$ & $*$ & $* *$ & $* * *$ & $* * *$ & \\
\hline
\end{tabular}

No statistical differences were found between SED-UNC and SUP-UNC 
$\mu \mathrm{g} \mathrm{L}^{-1}, \mathrm{n}=47$ ), Cornwallis Is. (3.80 $\left.\mu \mathrm{g} \mathrm{L}^{-1}, \mathrm{n}=44\right)$, and Somerset Is (4.09 $\left.\mu \mathrm{g} \mathrm{L}^{-1}, \mathrm{n}=9\right)$, while higher median TP concentrations were found on Coats Is. $\left(23.7 \mu \mathrm{g} \mathrm{L}^{-1}\right.$, $\mathrm{n}=10)$, Prince Charles Is., (14.8 $\left.\mu \mathrm{g} \mathrm{L}^{-1}, \mathrm{n}=5\right)$ and Ellef Ringnes Is. (11.3 $\left.\mu \mathrm{g} \mathrm{L}^{-1}, \mathrm{n}=25\right)$. Among geology types, significant differences $(\mathrm{P}<0.001)$ were found between IGN (median $\left.=6.0 \mu \mathrm{g} \mathrm{L}^{-1}, \mathrm{n}=332\right)$ and SED (median $=$ $7.4 \mu \mathrm{g} \mathrm{L}^{-1}, \mathrm{n}=825$ ), and between IGN and SUP (median $=7.7 \mu \mathrm{g} \mathrm{L}^{-1}, \mathrm{n}=77$; Tab. 4). Among ecoregions (Tabs. 5 and 7), significant differences were found for AC (median
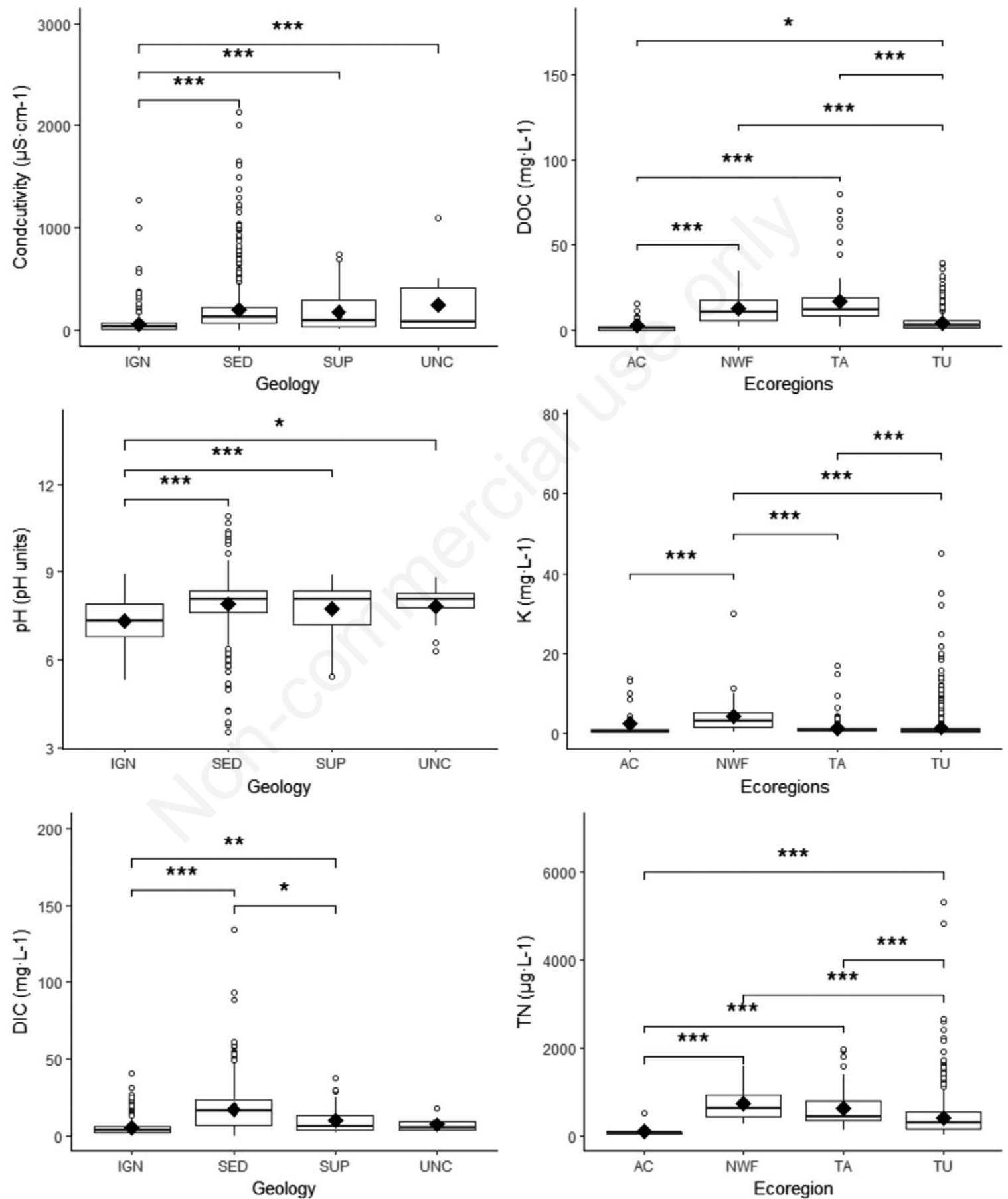

Fig. 5. Box plot of conductivity (left top), pH (left middle), and DIC (left bottom) among bedrock geology types, and DOC (right top), $\mathrm{K}$ (right middle), and TN (right bottom) among ecoregion types. Significant differences (Kruskal-Wallis rank sum test and Dunn's post hoc test with Bonferroni adjustment) between mean box plot concentrations are indicated by $* \mathrm{P}<0.05,{ }^{*} * \mathrm{P}<0.01, * * * \mathrm{P}<0.001$. 
$=6.0 \mu \mathrm{g} \mathrm{L}^{-1}, \mathrm{n}=23$ ) and NWF (median $=10.8 \mu \mathrm{g} \mathrm{L}^{-1}$, $\mathrm{n}=56 ; \mathrm{P}<0.01$ ), NWF and TA (median $=7.85 \mu \mathrm{g} \mathrm{L}^{-1}$, $\mathrm{n}=118 ; \mathrm{P}<0.05)$, and $\mathrm{NWF}$ and TU (median $=6.85 \mu \mathrm{g}$ $\left.\mathrm{L}^{-1}, \mathrm{n}=1050 ; \mathrm{P}<0.001\right)$.

Median total nitrogen (TN) concentrations was 312 $\mu \mathrm{g} \mathrm{L}^{-1}$ ( $\mathrm{n}=864$; Tab. 2). Cornwallis Is. had the lowest mean TN concentration $\left(73.1 \mu \mathrm{g} \mathrm{L}^{-1}, \mathrm{n}=4\right)$, followed by Baffin Is. (89.1 $\left.\mu \mathrm{g} \mathrm{L}^{-1}, \mathrm{n}=88\right)$, and Somerset Is. (110 $\mu \mathrm{g}$ $\mathrm{L}^{-1}, \mathrm{n}=8$ ) (Tab. 6). Higher TN concentrations were found on Southampton Is. (605 $\left.\mu \mathrm{g} \mathrm{L}^{-1}, \mathrm{n}=32\right)$, Prince Patrick Is. (591 $\left.\mu \mathrm{g} \mathrm{L}^{-1}, \mathrm{n}=35\right)$, and the Yukon $\left(540 \mu \mathrm{g} \mathrm{L}^{-1}, \mathrm{n}=22\right)$. Significant differences in TN concentration (Tab. 6, $\mathrm{P}<0.001$, Tabs. 4 and 7) were primary found between IGN (211 $\left.\mu \mathrm{g} \mathrm{L} \mathrm{L}^{-1}, \mathrm{n}=241\right)$ and SED geology (376 $\mu \mathrm{g} \mathrm{L}^{-1}$, $\mathrm{n}=590$ ). Among ecoregions, significant differences (all with $\mathrm{P}<0.001)$ occurred between $\mathrm{AC}\left(75 \mu \mathrm{g} \mathrm{L}^{-1}, \mathrm{n}=9\right)$ and NWF (613 $\left.\mu \mathrm{g} \mathrm{L}^{-1}, \mathrm{n}=16\right)$, TA (438 $\left.\mu \mathrm{g} \mathrm{L}^{-1}, \mathrm{n}=76\right)$ and TU $\left(286 \mu \mathrm{g} \mathrm{L}^{-1}, \mathrm{n}=763\right)$ and between TU and NWF $(613 \mu \mathrm{g}$ $\mathrm{L}^{-1}, \mathrm{n}=16$ ) and TA (Fig. 5 Bottom right; Tabs. 5 and 7).
Generally, most sites $(99.0 \%, \mathrm{n}=851)$ were found to be $\mathrm{P}$ limited (TN:TP > 17), while $1.0 \%(n=9)$ were N-limited systems (TN:TP < 14).

Dissolved Organic Carbon (DOC) concentrations were almost ten-times higher than Particulate Organic Carbon (POC) concentrations; median $=3.50 \mathrm{mg} \mathrm{L}^{-1}$ and $0.41 \mathrm{mg} \mathrm{L}^{-1}$, respectively (Tab. 2). Concentrations of DOC ranged from 0.02 to $69.9 \mathrm{mg} \mathrm{L}^{-1}$ (Tab. 2), reflecting the coverage of different ecoregions (Fig. 1). Among regions, higher median concentrations (Tab. 6) were found for Yukon (11.60 mg L $\mathrm{m}^{-1}, \mathrm{n}=59$ ), Northwest Territories (10.35 $\mathrm{mg} \mathrm{L}^{-1}, \mathrm{n}=118$ ), and Prince Patrick Is. (6.90 $\mathrm{mg} \mathrm{L}^{-1}, \mathrm{n}=35$ ), with the lowest concentrations found for Somerset Is. (0.78 $\left.\mathrm{mg} \mathrm{L}^{-1}, \mathrm{n}=9\right)$ ), Devon Is. (1.72 mg $\left.\mathrm{L}^{-1}, \mathrm{n}=64\right)$ and Cornwallis Is. (1.80 $\left.\mathrm{mg} \mathrm{L}^{-1}, \mathrm{n}=43\right)$. Similar to TN, DOC was found to be significantly different $\left(\mathrm{P}<0.01\right.$; Tab. 7) primary between IGN (2.90 $\mathrm{mg} \mathrm{L}^{-1}$, $\mathrm{n}=241)$ and SED geology (3.80 $\left.\mathrm{mg} \mathrm{L}^{-1}, \mathrm{n}=590\right)$ (Tab. 5). Among ecoregions, DOC concentrations differed

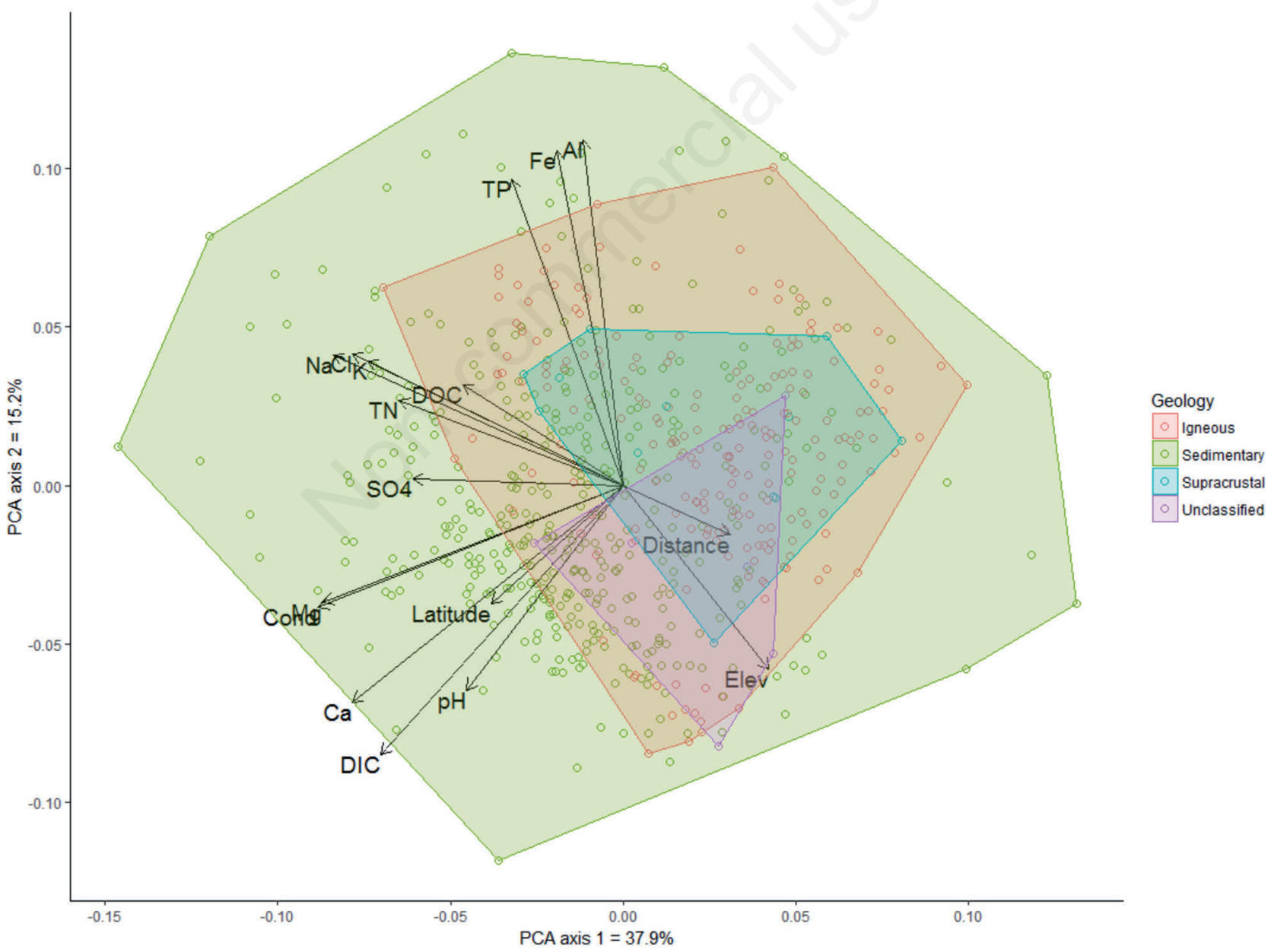

Fig. 6. Principal component analysis (PCA) of 17 physical and chemical variables for 613 sites (see Supporting Material F3) from across the Canadian Arctic. Sites are classified by four bedrock geology types from Harrison et al. (2011): igneous (red), sedimentary (green), supracrustal (blue), and unclassified (purple). 
significantly (Fig. 5 Top right, Tabs. 5 and 7) between AC (1.50 mg L $\left.{ }^{-1}, \mathrm{n}=21\right)$ and NWF $\left(10.6 \mathrm{mg} \mathrm{L}^{-1}, \mathrm{n}=53\right.$; $\mathrm{P}<0.001)$, TA (12.3 $\left.\mathrm{mg} \mathrm{L}^{-1}, \mathrm{n}=80 ; \mathrm{P}<0.001\right)$ and TU (3.15 $\mathrm{mg} \mathrm{L}^{-1}, \mathrm{n}=987 ; \mathrm{P}<0.05$ ). Strong correlations (Fig. 4) were found between DOC and TN $\left(\mathrm{r}_{\mathrm{s}}=0.81, \mathrm{P}<0.01\right)$, and DOC and TKN $\left(\mathrm{r}_{\mathrm{s}}=0.88, \mathrm{P}<0.01\right)$, while weaker correlations were found between POC with TP $\left(\mathrm{r}_{\mathrm{s}}=0.51\right.$, $\mathrm{P}<0.01)$, POC and TKN $\left(\mathrm{r}_{\mathrm{s}}=0.50, \mathrm{P}<0.01\right)$, and TP and $\mathrm{TN}\left(\mathrm{r}_{\mathrm{s}}=0.47, \mathrm{P}<0.01\right)$ (Fig. 4).

\section{Trace metals}

More than 40 trace metal species were reported $(n=42$; Supporting Material T1), with observations of $\mathrm{Al}(\mathrm{n}=872)$, $\mathrm{Ba}(\mathrm{n}=814), \mathrm{Fe}(\mathrm{n}=1015), \mathrm{Mn}(\mathrm{n}=875)$, and $\mathrm{Sr}(\mathrm{n}=819)$ reported more frequently (Tab. 2), along with $\mathrm{Zn}, \mathrm{Cu}$, and $\mathrm{Li}$, which had observations at $>500$ sites (see Supporting Material T1). See Supporting Material for summary statistics for other trace metals, e.g., $\mathrm{Cd}(\mathrm{n}=264)$ and $\mathrm{Pb}$ $(\mathrm{n}=366)$ had maximum concentrations of $11.0 \mu \mathrm{g} \mathrm{L}^{-1}$ (Proteus Lake, Hamilton et al., 2001), and $52 \mu \mathrm{g} \mathrm{L}^{-1}$ (CI26, Bouchard et al., 2004). These data may be used to assess trace metal toxicity, or possibly to indicate contamination; however, this was not the aim of the current study. The spatial coverage of sites $(n=1022$, $78.6 \%$ ) with observations of one or more selected trace metals (Al, Fe, Mn) had gaps primarily on Bylot Is., mainland Northwest Territories and Nunavut, central Baffin Is., southwestern Bathurst Is., and parts of Ellesmere Is. (see Supporting Material F7).

From this subset of trace metals (Tab. 2), higher median concentrations were observed for $\mathrm{Al}, \mathrm{Ba}, \mathrm{Fe}, \mathrm{Mn}$, and Sr: $17.0 \mu \mathrm{g} \mathrm{L}^{-1}(\mathrm{n}=872), 6.5 \mu \mathrm{g} \mathrm{L}^{-1}(\mathrm{n}=814), 48.0 \mu \mathrm{g}$ $\mathrm{L}^{-1}(\mathrm{n}=1015), 5.3 \mu \mathrm{g} \mathrm{L}^{-1}(\mathrm{n}=875)$, and $23.9 \mu \mathrm{g} \mathrm{L}^{-1}$ $(\mathrm{n}=819)$, respectively. By region (Tab. 6), higher median values were found for $\mathrm{Al}$ on Ellef Ringnes Is. $(180 \mu \mathrm{g}$ $\left.\mathrm{L}^{-1}, \mathrm{n}=25\right), \mathrm{Ba}$ on Bathurst Is. (34.5 $\left.\mu \mathrm{g} \mathrm{L}^{-1}, \mathrm{n}=64\right), \mathrm{Fe}$ on Prince Patrick Is. (267 $\left.\mu \mathrm{g} \mathrm{L}^{-1}, \mathrm{n}=35\right), \mathrm{Mn}$ in the Northwest Territories (44.0 $\left.\mu \mathrm{g} \mathrm{L}^{-1}, \mathrm{n}=109\right)$, and $\mathrm{Sr}$ in Yukon $(174 \mu \mathrm{g}$ $\left.\mathrm{L}^{-1}, \mathrm{n}=33\right)$. The lowest median values were found for $\mathrm{Al}$ $\left(5.18 \mu \mathrm{g} \mathrm{L}^{-1}, \mathrm{n}=4\right)$ and $\mathrm{Ba}\left(1.27 \mu \mathrm{g} \mathrm{L}^{-1}, \mathrm{n}=4\right)$ on Prince Charles Is., Fe (5.00 $\left.\mu \mathrm{g} \mathrm{L}^{-1}, \mathrm{n}=45\right)$ and $\mathrm{Mn}\left(0.40 \mu \mathrm{g} \mathrm{L}{ }^{-1}\right.$, $\mathrm{n}=45$ ) on Axel Heiberg Is., and $\mathrm{Sr}$ in the Northwest Territories $\left(12.00 \mu \mathrm{g} \mathrm{L}^{-1}, \mathrm{n}=61\right)$.

For geology type, significant differences were found between IGN-SUP for $\mathrm{Al}$ and Mn (Tabs. 4 and 7), i.e., [Al] IGN $=12.8 \mu \mathrm{g} \mathrm{L}^{-1}, \mathrm{n}=225$ and $\mathrm{SUP}=29.0 \mu \mathrm{g} \mathrm{L}^{-1}$, $\mathrm{n}=37(\mathrm{P}<0.001)$; $[\mathrm{Mn}] \mathrm{IGN}=6.57 \mu \mathrm{g} \mathrm{L}{ }^{-1}, \mathrm{n}=236$ and SUP $=7.35 \mu \mathrm{g} \mathrm{L}^{-1}, \mathrm{n}=42(\mathrm{P}<0.01)$. For Ba (Tabs. 4 and 7), differences were found between IGN $\left(4.00 \mu \mathrm{g} \mathrm{L}^{-1}, \mathrm{n}=215\right)$ with SED $\left(7.89 \mu \mathrm{g} \mathrm{L}^{-1}, \mathrm{n}=551\right)$ and SUP $\left(18.7 \mu \mathrm{g} \mathrm{L}^{-1}\right.$, $\mathrm{n}=39$ ) (both with $\mathrm{P}<0.001$ ), and SED with SUP $(\mathrm{P}<0.05)$. For $\mathrm{Sr}$ (Tabs. 4 and 7), differences were found between IGN $\left(14.5 \mu \mathrm{g} \mathrm{L}^{-1}, \mathrm{n}=215\right)$ with SED $\left(30.1 \mu \mathrm{g} \mathrm{L}^{-1}, \mathrm{n}=556\right.$; $\mathrm{P}<0.001)$, SUP $\left(116 \mu \mathrm{g} \mathrm{L}^{-1}, \mathrm{n}=39 ; \mathrm{P}<0.001\right)$, UNC (28.0 $\left.\mu \mathrm{g} \mathrm{L}^{-1}, \mathrm{n}=9 ; \mathrm{P}<0.05\right)$, and SED and SUP $(\mathrm{P}<0.001)$. No significant differences were found for $\mathrm{Fe}$ across all geology types. Strong correlations were found between $\mathrm{Sr}-\mathrm{Cond}\left(\mathrm{r}_{\mathrm{s}}=0.80\right)$ and $\mathrm{Sr}-\mathrm{Ca}\left(\mathrm{r}_{\mathrm{s}}=0.78\right)$ (all $\mathrm{P}<0.01$; Fig. 4). A weak correlation was observed between $\mathrm{Fe}-\mathrm{Al}\left(\mathrm{r}_{\mathrm{s}}=\right.$ $0.52 ; \mathrm{P}<0.01)$ and $\mathrm{Ba}-\mathrm{Sr}\left(\mathrm{r}_{\mathrm{s}}=0.66 ; \mathrm{P}<0.01\right)$.

Among ecoregions, $\mathrm{Al}$ and $\mathrm{Fe}$ had only one significant difference (Tabs. 5 and 7); [Al] TA $\left(30.0 \mu \mathrm{g} \mathrm{L}^{-1}, \mathrm{n}=16\right)$ and TU $\left(13.8 \mu \mathrm{g} \mathrm{L}^{-1}, \mathrm{n}=771 ; \mathrm{P}<0.05\right)$ and $[\mathrm{Fe}] \mathrm{AC}(100$ $\left.\mu \mathrm{g} \mathrm{L}^{-1}, \mathrm{n}=16\right)$ and NWF $\left(32.5 \mu \mathrm{g} \mathrm{L}^{-1}, \mathrm{n}=56 ; \mathrm{P}<0.05\right)$. Manganese was significantly different (Tabs. 5 and 7) between NWF $(12.9 \mu \mathrm{g} \mathrm{L}-1, \mathrm{n}=55)$ and TU $\left(4.43 \mu \mathrm{g} \mathrm{L}^{-1}\right.$, $\mathrm{n}=729)$, TA (61.0 $\left.\mu \mathrm{g} \mathrm{L}^{-1}, \mathrm{n}=81\right)$ and TU (both $\left.\mathrm{P}<0.001\right)$, and $\mathrm{AC}\left(8.34 \mu \mathrm{g} \mathrm{L}^{-1}, \mathrm{n}=10\right)$ and $\mathrm{TU}(\mathrm{P}<0.05)$. For $\mathrm{Ba}$ and $\mathrm{Sr}$, significant difference among ecoregions (Tabs. 5 and 7) were found between $\mathrm{AC}([\mathrm{Ba}=1.46, \mathrm{n}=9],[\mathrm{Sr}=3.68$, $\mathrm{n}=9])$ and NWF ([Ba $=32.0, \mathrm{n}=33],[\mathrm{Sr}=174, \mathrm{n}=33])$ $(\mathrm{P}<0.001), \mathrm{AC}$ and $\mathrm{TA}([\mathrm{Ba}=5.00, \mathrm{n}=53],[\mathrm{Sr}=19.0$, $\mathrm{n}=53])(\mathrm{Ba}=\mathrm{P}<0.05, \mathrm{Sr}=\mathrm{P}<0.01), \mathrm{NWF}$ and $\mathrm{TA}$ $(\mathrm{P}<0.001)$, and $\mathrm{NWF}$ and TU $([\mathrm{Ba}=6.37, \mathrm{n}=719],[\mathrm{Sr}=$ 23.0, $\mathrm{n}=24])(\mathrm{P}<0.001)$.

\section{Drivers and relationships of water chemistry}

Principal component analysis was used to determine key relationships among water chemistry variables, and the variability within the dataset (Fig. 6). The PCA was limited to 17 variables that were common across 613 sites (see Supporting Material F3). Components one and two explained a total of $53.4 \%$ (PCA $1=37.9 \%$ and PCA $2=$ $15.5 \%$ ) of the variation (Fig. 6). Eigenvalues $(\lambda)$ were 6.44 for Component 1, 2.58 for Component 2, 2.08 for Component 3, 1.41 for Component 4, and 1.15 for Component 5. Although Component 3, 4, and 5 had eigenvalues $>1.0$, they accounted for small portions of the variation $(12.2 \%, 8.3 \%$, and $6.7 \%$, respectively), and were not examined further (their loadings are given in Supporting Material T2). Variables that influenced Component 1 were (in descending order) Cond $>\mathrm{Mg}>$ $\mathrm{Na}>\mathrm{Ca}>\mathrm{Cl}$. This suggests that Component 1 represented weathering of carbonate materials, such as those found on SED geology. Variables associated with Component 2 were: $\mathrm{Al}, \mathrm{Fe}$, and TP, suggesting terrestrial sources (soil or geology) of TP; Al, Fe, and TP were correlated with each other $(\mathrm{P}<0.01$; Fig. 4). Similarly, Cond, $\mathrm{Mg}$, and $\mathrm{Ca}$ were clustered with $\mathrm{DIC}$ and $\mathrm{pH}$ (Fig. $6)$ and were highly correlated ( $<<0.01$; Fig. 4).

\section{DISCUSSION}

This study synthesized observations of water chemistry from 1300 Arctic lakes and ponds spanning a period of 37 years (centred on period between 1990 to 2010, $\mathrm{n}=1050$ ) and updates and complements studies by 
Hamilton et al. (2010) and Dranga et al. (2018). It is recognized that there is a need to establish further baseline water chemistry studies (including data other than $\mathrm{pH}$, conductivity, dissolved oxygen, and water temperature), especially within regions with known data gaps (AMAP, 2005; Adrian et al., 2009; Bégin et al., 2017). Hydrochemical information is especially important if anthropogenic activities such as shipping (and the associated emissions) are expected to increase into future (Pizzolato et al., 2016), potentially impacting Arctic freshwater bodies (Liang and Aherne, 2019). Equally, temporal studies are needed (Roberts et al., 2017; Lougheed et al., 2011), as changes such as the prolonging of the growing season (Rouse et al., 1997) and reduction of ice-cover days (Surdu et al., 2016) have occurred within the Arctic region and are expected to impact physical, biological, and chemical processes in aquatic ecosystems.

In this study, the water chemistry of Arctic lakes and ponds was primarily differentiated along a conductivity / cation and trace metal / nutrient gradient (Fig. 6). The conductivity / cation gradient has been previously reported by other limnological studies (Pienitz et al., 1997a; Hamilton et al., 2001; Michelutti et al., 2002a, 2002b; Antoniades et al., 2003a, 2003b; Rühland et al., 2003; Lim et al., 2005; Mallory et al., 2006; Lougheed et al., 2011), as most study sites are situated over SED geology (66.5\%, n=864; Fig. 2 Top; Tab. 4). The metal $(\mathrm{Al}, \mathrm{Fe})$ and phosphorus gradient observed in this study, is similar to other studies that have reported a combination of nutrient (POC, DOC, TNU, PON, TPF, TP) and metal (Al, Fe, Zn, and $\mathrm{Mn}$ ) gradients (Pienitz et al., 1997a; Michelutti et al., 2002a; Antoniades et al., 2003a). Other studies have reported physical and climatic conditions, i.e., depth and temperature, as the main drivers of water chemistry (Pienitz et al., 1997a; Rühland et al., 2003; Dranga et al., 2017), which may be explained through more localized drivers, higher biogeochemical cycling under higher temperatures and/or different cycling between ponds and lakes. Although depth and temperatures were not included in the PCA in the current study (Fig. 6), depth was explored though correlations (Fig. 4), which indicated significant $(\mathrm{P}<0.01)$ weak correlations between lake depth and $\mathrm{Mg}\left(r_{s}=-0.31\right)$, Cond $\left(r_{s}=-0.31\right), \mathrm{Ca}\left(r_{s}=-0.25\right), \mathrm{Cl}\left(r_{s}=-0.42\right), \mathrm{Fe}\left(r_{s}\right.$ $=-0.59), \mathrm{NH}_{3}\left(r_{s}=-0.35\right), \mathrm{TKN}\left(r_{s}=-0.38\right), \mathrm{TN}\left(r_{s}=-\right.$ $0.39)$, POC $\left(r_{s}=-0.35\right)$, and TP $\left(r_{s}=-0.39\right)$, similar to other studies (Lim et al., 2001; Medeiros et al., 2012) that indicated more dilution (lower concentration of ions, nutrients, and metals) among deeper systems.

\section{Geology as a driver of water chemistry}

It is well established that geology can influence surface water $\mathrm{pH}$ (Michelutti et al., 2002a, 2002b;
Antoniades et al., 2003a, 2003b; Lim et al., 2005; Westover et al., 2009). Lakes situated on SED geology tended to be more alkaline (median $\mathrm{pH}=8.06, \mathrm{n}=826$ ) compared with those situated on IGN geology (median $\mathrm{pH}=7.31, \mathrm{n}=328$; Tab. 4). One study (Michelutti et al., 2010) reported a mean $\mathrm{pH}$ of $8.1(\mathrm{n}=407$; range $=3.6-9.0)$ for sites in the Canadian High Arctic, which was more alkaline than this study $($ mean $=6.01$; range $=3.4-10.9$; Tab. 2), potentially owing to their limited regional coverage, where geology was predominately sedimentary (Clague et al., 1989; Dawes and Christie, 1991, 1991; Fig. 2 Top). The PCA clustering of $\mathrm{pH}$ and conductivity with $\mathrm{Ca}, \mathrm{Mg}$, and DIC (Fig. 6) suggests that $\mathrm{pH}$ and conductivity are largely influenced by the weathering of carbonate rich sedimentary geology (Harris et al., 2012), which is composed of limestone $\left(\mathrm{CaCO}_{3}\right)$ and dolostone $\left(\mathrm{CaMg}\left(\mathrm{CO}_{3}\right)_{2}\right)$.

Surface waters situated on the IGN geology type, were significantly different from those located on the other geological types, and they were generally associated with lower concentrations of base cations, nutrients, and metals (Fig. 5 Left middle; Tabs. 4 and 7). This is largely attributed to the higher quartz $\left(\mathrm{SiO}_{2}\right)$ content of the IGN lithology, e.g., granite and rhyolite $>69 \% \mathrm{SiO}_{2}$, Trachyte $\sim 63 \% \mathrm{SiO}_{2}$, and gabbro and basalt $45-52 \% \mathrm{SiO}_{2}$ (Hodgson, 2005; Harris et al., 2012), which provides limited buffering capacity against inputs of acidity (Dupont et al., 2005). Nonetheless, hydrochemical outliers were observed within each bedrock geology type, e.g., sites with high $\mathrm{pH}$ were observed on IGN geology. This is likely an artefact of the scale of the underlying geological mapping (scale of 1:5,000,000; Harris et al., 2012), which was not able to capture localized variations.

Localized geology can have a significant impact on water chemistry, e.g., one study (Antoniades et al., 2003b) assessed the $\mathrm{pH}$ of 25 sites within a $7.5 \mathrm{~km}$ radius, which resulted in a range of values from acidic 5.1 to more alkaline values of 7.9. This suggest that lakes and ponds are greatly influenced by localized geology, which can be highly spatially variable. Certain geologies may contain higher concentrations of sulphur, such as pyrite $\left(\mathrm{FeS}_{2}\right)$ containing shale, e.g., Smoking Hills, NWT (Havas and Hutchinson, 1983; Hodgson, 2005), which when oxidised in the presence of water, produces sulphate $\left(\mathrm{SO}_{4}\right)$ and acidity $\left(\mathrm{H}^{+}\right)$that can leach into nearby aquatic systems (acid rock drainage). Previous studies have reported sites with $\mathrm{pH}<4.0$ influenced by the oxidation of $\mathrm{SO}_{4}$ soils (Michelutti et al., 2002a; Antoniades et al., 2003a; Johannesson and Lyons, 1995) resulting in higher $\mathrm{SO}_{4}$ concentrations in surface waters (Havas and Hutchinson, 1983; Michelutti et al., 2002; Antoniades et al., 2003a). Two sites surveyed in the current study (KM_6, and KM_7 near Kimmirut) had $\mathrm{pH}<4.0$ and high $\mathrm{SO}_{4}$ concentrations $\left(>50 \mathrm{mg} \mathrm{L}^{-1}\right)$ attributed to iron sulphide 
minerals commonly found on the Meta Incognita Peninsula (Hodgson, 2005).

\section{Drivers of $\mathrm{Na}$ and $\mathrm{Cl}$}

Elevated concentrations of $\mathrm{Na}$ and $\mathrm{Cl}$ in Arctic lakes and ponds are commonly associated with the influence of sea-salt aerosols, especially among coastal sites (Pienitz et al., 1997a; Lim et al., 2001 Michelutti et al., 2002a; Antoniades et al., 2003b; Mallory et al., 2006; Cöte et al., 2010; Hadley et al., 2013). Of the 1251 sites with observations of $\mathrm{Na}$ and $\mathrm{Cl}$, approximately $61.2 \%(\mathrm{n}=766)$ had ratios $>0.86$, which suggests some contribution from the weathering of bedrock geology and the soil cation exchange complex. Although, $\mathrm{Na}$ is largely attributed to sea-salt aerosols, other sources such as the weathering of bedrock, especially for sites on shale (McNeel et al., 1979; Cerling et al., 1989). In general, the concentration of sea-salts (primary $\mathrm{Na}$ and $\mathrm{Cl}$ ) decreases exponentially from the coast to $200 \mathrm{~km}$ inland, where concentrations remain stable (Suzuki et al., 2002). In this study, most sites were situated within $<200 \mathrm{~km}(88.6 \%, \mathrm{n}=1153)$ from the coast (Fig. 3) and at low elevations, $<100 \mathrm{~m}$ asl $(40.3 \%, \mathrm{n}=524)$, which suggests a sea-salt influence, as evidenced by the strong correlation between $\mathrm{Na}$ and $\mathrm{Cl}\left(r_{s}\right.$ $\geq 0.85, \mathrm{P}<0.01$, Fig. 4) and their clustering in the PCA (Fig. 6).

\section{Drivers of nutrients}

In generally, most Arctic lakes and ponds in this study were nutrient poor, with TP the limiting factor for primary productivity. We found that $45.6 \%$ of sites were oligotrophic (4.0-10.0 $\mu \mathrm{g} \mathrm{L}^{-1}$ of TP; CCME, 2004) and $24.8 \%$ were ultra-oligotrophic $\left(<4.0 \mu \mathrm{g} \mathrm{L}^{-1}\right.$ of TP; CCME, 2004). Phosphorous can enter the aquatic system through external loading, such as that from the decay of vegetation matter (Antoniades et al., 2003b), mammal and avian feces (Lim et al., 2001; Mallory et al., 2006; Hessen et al., 2017) and runoff over phosphorus geology (Hamilton et al., 2001). The clustering of Al, Fe, and TP (Fig. 6) and the weak correlation between TP with $\mathrm{Fe}\left(r_{s}=0.44\right)$ and POC $\left(r_{s}=0.50\right)(\mathrm{P}<0.01$; Fig. 4) suggest allochthonous (outside of the aquatic system) inputs of phosphorus such as from geological sources from strengite $\left(\mathrm{FePO}_{4} 2 \mathrm{H}_{2} \mathrm{O}\right)$ and carbonatite, or SED phosphorites found in shale or chert (Konhauser et al., 1994; Hamilton et al., 2001; Antoniades, et al., 2003a; Harrison et al., 2011). Large Arctic avian colonies, such as those by the Greater Snow Geese (Chen caerulescens atlanticus), Lesser Snow Geese (Chen caerulescens caerulescens) and Ross's goose (Chen rossii), have been known to cause vegetation degradation within lake catchments (Alisauskas et al., 2006; Hines et al., 2010) and enhance phosphorus concentration within surface waters (Mallory et al., 2006;
Brimble et al., 2009; Côte et al., 2010; Michelutti et al., 2010). However, it is unknown if this is the mechanism for the 39 sites classified as eutrophic or hyper-eutrophic in the current study. Although these processes (inputs from geological and biological sources) suggest high inputs of phosphorus, in reality TP availability is often limited. Since most sites (with available data) are shallow $(85.4 \%, \mathrm{n}=581$; Fig. 3 Bottom) and small (58.0\%, n 509, at $\leq 10 \mathrm{ha}$; Hamilton et al., 2001), they are generally more oxic environments that bind phosphorus to iron (III) compounds in lake sediment (Mortimer, 1941; Søndergaard et al., 2003). Whalen and Cornwell (1985) suggest that most phosphorus enters polar lakes through streams and runoff and is removed though sedimentation and burial.

When using TN concentration to determine trophic status, $54.9 \%(n=474)$ of the sites were considered to be oligotrophic (TN <350 $\mu \mathrm{g} \mathrm{L}^{-1}$; Nürnberg, 1996). Past studies of Arctic aquatic systems (Alexander et al., 1989; Ditmar and Kattner, 2003) suggest that inputs of nitrogen are primarily the result of nitrogen fixation from algae and cyanobacteria (Whalen and Cornwell, 1985; Alexander et al., 1989). Strong correlations between nitrogen species (TN and TKN) with DOC $\left(\mathrm{r}_{\mathrm{s}}=0.81, \mathrm{r}_{\mathrm{s}}=0.88, \mathrm{P}<0.01\right.$; Fig. 4) may reflect allochthonous inputs of organic nitrogen. Some have attributed elevated TN concentration with the input of feces from large bird colonies (Mallory et al. 2006; Brimble et al., 2009; Keatley et al., 2009; Michelutti et al., 2010). However, these cases were not found to be common across our results, i.e., the majority of sites were nutrient poor (oligotrophic $=45.6 \%$ and ultra-oligotrophic $=24.8 \%$ ). This large input of nitrogen (from feces) can enhance vegetation development as nitrogen is more limiting than phosphorus in terrestrial tundra ecosystems (Elser et al., 2007). For example, Bazely and Jefferies (1985) reported that the increase in biomass of Creeping goose grass (Puccinellia phryganodes) and Hoppner's sedge (Carex subspathacea) were significant $\left(\mathrm{P}<0.01\right.$; mean of geese site $=199 \mathrm{~g} \mathrm{~m}^{-3}$ $v s$ non-geese sites $=122 \mathrm{~g} \mathrm{~m}^{-3}$ ) when plots were treated with geese feces. It is suggested that increased vegetation production could be the result of inputs of geese feces (soluble nitrogen) from large flocks (>5000 pairs of Lesser Snow Geese) of waterfowl, such as that observed by Bazely and Jefferies (1985).

Carbon across Arctic aquatic systems is predominately found in the form of DOC; median DOC across the Canadian high Arctic has been previously reported to be $3.0 \mathrm{mg} \mathrm{L}^{-1}(\mathrm{n}=404$; Michelutti et al., 2010), which is slightly lower than found in this study (3.50 mg L ${ }^{-1}, \mathrm{n}=1135$; Tab. 2). This can be attributed to the inclusion of lower latitude studies, e.g., Moser et al. (1998), Wilson and Gajewski (2002), Rühland et al., (2003), in the NWF and TA ecoregions (Fig. 2 Bottom; 
Tab. 1). However, lower DOC concentrations across the Arctic may be attributed to slow biogeochemical processes owing to lower surface and subsurface temperatures. Vegetation and soils within catchments provide an allochthonous source of organic carbon via terrestrial runoff, especially during the spring melt (Neff et al., 2016). Further, carbon sources change from recent organic matter, i.e., vegetation litter and surface soil horizons, during the spring to older stored carbon during the late summer. Other studies have reported higher DOC concentrations with more lush vegetated catchments (Lim et al., 2001, 2005; Wilson and Gajewski, 2002; Antoniades et al., 2003a; Rühland et al., 2003). The weak but significant correlations observed between DOC with $\mathrm{K}\left(r_{s}=0.54, \mathrm{P}<0.01\right.$, Fig. 4) supports vegetation driven DOC as $K$ is an essential nutrient. However, it should be noted that DOC concentrations may also be influenced by localized characteristics such as organic soils, catchment connectivity, thawing of permafrost, and discharge from wetlands (Tarnocai, 2003; Sobek et al., 2007; Rautio et al., 2011; Amon et al., 2012).

\section{Changes to water chemistry}

Global, regional, and localized anthropogenic activities may impact the water chemistry of arctic lakes and ponds. Global climatic change is expected to increase rates of precipitation in the Arctic (7.5-18.1\% greater) with larger portions occurring as rain (Kattsov et al., 2005; AMAP, 2017). Higher air temperatures (leading to the thawing of permafrost) and (wet) precipitation volumes can increase the transportation (via runoff) of solutes and nutrients into aquatic environments, thus changing their physical (Osterkamp and Romanovsky, 1999; Payette et al., 2004; Smith et al., 2005; Romanovsky et al., 2010; Plug et al., 2008) and chemical characteristics (Prowse et al., 2006; Walvoord and Strieg, 2007). A recent study (Roberts et al., 2017), reported that increased solute mobilization and catchment drainage from increased summer precipitation and higher temperature caused an increase of $+500 \%$ and $+340 \%$ in sulphate concentrations (from 5 to $17 \mathrm{mg} \mathrm{L}^{-1}$ and from 3 to $15 \mathrm{mg} \mathrm{L}^{-1}$ ) from 2006 to 2016 in two high Arctic lakes. In addition, concentrations of $\mathrm{Ca}(\sim 50 \%), \mathrm{Mg}(\sim 75 \%), \mathrm{K}$ ( $\sim 25$ to $75 \%)$, and $\mathrm{Na}(\sim 75$ to $100 \%)$ also increased between 2003 and 2015 (Robert et al., 2017). Further, Thienpont et al. (2013), reported that disturbed lakes $(n=5)$ had higher ionic concentrations when compared to reference lakes $(n=5)$ with no disturbance from thaw slumping. These large changes in water chemistry from enhanced catchment processes (owing to climatic change) illustrate the urgency to capture hydrochemical data prior to disturbances and the need for long-term monitoring sites across the Canadian Arctic. The full impacts of physical and chemical changes to aquatic systems are unknown, as both positive (Lamoureux and Gilbert, 2004; Michelutti et al., 2005, 2007; Thienpont et al., 2013) and negative (Reist et al., 2006; Robert et al., 2017) changes to biological communities have been shown.

Atmospheric transport of pollutants can have far reaching impacts to Arctic lakes and ponds. Inputs of pesticides (Zhang et al., 2013), heavy metals (Outridge et al., 2002), and acidifying pollutants (sulphur and nitrogen, Forsius et al., 2010) can influence the chemical characteristics and the biological communities of aquatic ecosystem. Further, localized anthropogenic activities (Fig. 1) near population centers (Bunbury and Gajewski, 2002; Michelutti et al., 2007a; Hamilton et al., 2010; Medeiros et al., 2012; Liang and Aherne, 2019) and roadways (Moser et al., 1993; Bunbury and Gajewski, 2002; Pienitz et al., 1997a), can influence the water chemistry of lakes and ponds. Discharge from wastewater treatment plants has been found to greatly elevate nutrient concentrations resulting in oxygen depletion, altered sediment conditions, and reduced hatching rates of fish (Schindler et al.,1974; Douglas and Smol, 2000; Moiseenko et al., 2009). Similarly, anthropogenic structures such as paved and gravel roads (calcareous road dust) have been shown to elevate conductivity, $\mathrm{pH}$, and major ions in aquatic systems (Spatt, 1978; Everett, 1980; Gunter, 2017; Zhu, 2019).

\section{Limitations of this study}

In the current study, the data window spanned more than 30 years; it is likely that water chemistry has changed during this period owing to natural and anthropogenic pressures, which may have influenced our results. Unfortunately, we did not have access to long-term records from discrete monitoring locations to evaluate the potential changes. Robert et al. (2017) reported changes to the physical and chemical characteristics of two adjacent lakes (in separate watersheds) within a span of 13 years. They found that $\mathrm{Mg}, \mathrm{Na}, \mathrm{SO}_{4}, \mathrm{Cl}$, and specific conductivity increased while other chemical parameters such as $\mathrm{Ba}, \mathrm{Fe}, \mathrm{Mn}$, and $\mathrm{Zn}$, decreased between 2003 and 2015. Further, our study was limited by gaps in spatial coverage as chemical variables were not available for all 1300 sites (see Supporting Material F4, F5, F6, and F7, to understand the spatial coverage of selected chemical variables).

The initial database had numerous observations below detection for trace metal species. While we attempted to impute these missing values to prevent bias (see methods), the analysis of trace metals is nonetheless uncertain, e.g., As $(n=244)$ had a maximum observed concentration of $17.1 \mu \mathrm{g} \mathrm{L}^{-1}$ (see Supporting Material T1) as a result of a detection limit of $<20.0 \mu \mathrm{g} \mathrm{L}^{-1}$ (Turnabout Lake, Babbaluk et al., 2009). 


\section{CONCLUSIONS}

Few studies have provided an overview of Arctic water chemistry on a regional scale (Hamilton et al., 2001; Medeiros et al., 2012; Dranga et al., 2018). In general, bedrock geology dictates the chemistry of Arctic surface waters, with significant differences between sites on sedimentary compared with igneous geology. Lakes on sedimentary bedrock tend to be alkaline, and have higher concentrations of major ions, nutrients, and trace metals than those on igneous geology. Nonetheless, localized characteristics such as proximity to the coast, minerology (pyrite or carbonate minerals) and biological communities (avian colonies or vegetation) can also greatly impact $\mathrm{pH}$, concentrations of metals, and nutrient inputs.

Changes within the cryosphere under climate change and from anthropogenic activities are expected to impact the Arctic landscape and will ultimately change the chemistry of Arctic lakes and ponds. Current Arctic limnological studies are limited owing to logistical constraints, which has resulted in spatial and temporal data (and knowledge) gaps, and a grab-what-you-can sampling design. Localized limnological studies with comprehensive hydrochemical observations are needed to fill known spatial gaps, such as those on Baffin Is, Prince of Wales Is., southwestern Victoria Is., and the northern mainland of Yukon and Northwest Territories (other than the Mackenzie basin). Ultimately, knowledge of the baseline limnological characteristic of Arctic lakes and ponds is central to assessing the potential impacts from anthropogenic activity, such as those from increased shipping (Pizzolato et al., 2016; Liang and Aherne, 2019). In addition, and equally as important, is the need for longterm studies (Roberts et al., 2017), or to some extent the re-survey of sites (Lougheed et al., 2011), to support the assessment of climate change impacts on Arctic aquatic ecosystems.

\section{ACKNOWLEDGMENTS}

This study was funded by the Natural Science and Engineering Research Council (NSERC) grant awarded to Julian Aherne, as well as the McLean foundation and Northern Studies Training Programme (NSTP) award to Tanner Liang. We are thankful for financial support from Environment and Climate Change Canada (GCXE15Z268, GCXE17C090 and GCXE19S022), Career Launcher Internship support from Colleges and Institutes Canada, and logistical support from the Nunavut Research Institute (NRI) and the Polar Continental Shelf Program (PCSP). We thank the many authors of the various publication for making their data available and comments from two anonymous reviewers that greatly helped to improve this study. Thanks to Phaedra Cowden, Dr. Scott Fleming, Dr. Peter Lafleur for their assistance in the field, Kevin Adkinson and the team at Trent University's Water Quality Centre for their laboratory support, and to Hazel Cathcart for her GIS assistance.

\section{REFERENCES}

Adams HE, Crump BC, Kling GW, 2010. Temperature controls on aquatic bacterial production and community dynamics in arctic lakes and streams. Environ. Microbiol. 12;1319-1333.

Adrian R, O'Reilly CM, Zagarese H, Baines SB, Hessen DO, Keller W, Livingstone DM, Sommaruga R, Straile D, Van Donk E, Weyhenmeye, GA, Winder M, 2009. Lakes as sentinels of climate change. Limnol. Oceanogr. 54:2283-2297.

Alexander V, Whalen SC, Klingensmith KM, 1989. Nitrogen cycling in Arctic lakes and ponds, p. 165-172. In: V. Warwick and J.C. Ellis-Evans (eds.), High Latitude Limnology. Springer, Dordrecht.

Aliabadi AA, Staebler RM, Sharma S, 2015. Air quality monitoring in communities of the Canadian Arctic during the high shipping season with a focus on local and marine pollution. Atmos. Chem. Phys. 15:2651-2673.

Alisauskas RT, Charlwood J, Kellett DK, 2006. Vegetation correlates of nesting history and density by Ross's and lesser snow geese at Karrak Lake, Nunavut. Arctic 59:201-210.

Amon RMW, Rinehart AJ, Duan S, Louchouarn P, Prokushkin A, Guggenberger G, Bauch D, Stedmon C, Raymond PA, Holmes RM, McClelland JW, 2012. Dissolved organic matter sources in large Arctic rivers. Geochim. Cosmochim. Acta 94:217-237.

Antoniades D, Douglas MSV, Smol JP, 2003a. Comparative physical and chemical limnology of two Canadian High Arctic regions: Alert Ellesmere Is., NU and Mould Bay Prince Patrick Is., NWT. Archiv Hydrobiol 158:485-516.

Antoniades D, Douglas MSV, Smol JP, 2003b. The physical and chemical limnology of 24 ponds and one lake from Isachsen, Ellef Ringnes Is., Canadian High Arctic. Int. Rev. Hydrobiol. 88:519-538.

Arctic Monitoring and Assessment Programme, 1998. AMAP Assessment Report: Arctic Pollution issues. Arctic Monitoring and Assessment Programme AMAP. Available from: https://www.amap.no/documents/doc/amap-assessmentreport-arctic-pollution-issues/68

Arctic Monitoring and Assessment Programme, 2017. Snow, Water, Ice and Permafrost in the Arctic (SWIPA). Arctic Monitoring and Assessment Programme AMAP. Available from: https://www.amap.no/documents/doc/snow-water-iceand-permafrost-in-the-arctic-swipa-2017/1610

Babaluk JA, Gantner N, Michaud W, Muir DCG, Power N, Reist JD, Sinnatamby R, Wang X, 2009. Chemical analyses of water from lakes and streams in Quttinirpaaq National Park, Nunavut, 2001-2008. Canadian Data Report of Fisheries and Aquatic Sciences, Winnipeg; 1217 pp.

Babaluk JA, Heuring LG, Reist JD, Billeck BN, 1999. Selected chemical analyses of water from lakes in Ellesmere Is. National Park Reserve, Northwest Territories. Canadian Data Report of Fisheries and Aquatic Sciences, Winnipeg; $1250 \mathrm{pp}$. 
Bazely DR, Jefferies RL, 1985. Goose Faeces: A source of nitrogen for plant growth in a grazed salt marsh. J. Appl. Ecol. 22:693-703.

Bégin PN, Lebedeva L, Tashyreva D, Velazquez D, Blaen PJ, 2017. Future priorities for Arctic freshwater science from the perspective of early-career researchers. Arctic Sci. 3:661-671.

Bouchard G, Gajewski K, Hamilton PB, 2004. Freshwater diatom biogeography in the Canadian Arctic Archipelago. J. Biogeogr. 31:1955-1973.

Brimble SK, Blais JM, Kimpe LE, Mallory ML, Keatley BE, Dougla, MSV, Smol JP, 2009. Bioenrichment of trace elements in a series of ponds near a northern fulmar Fulmarus glacialis colony at Cape Vera, Devon Island. Can. J. Fish. Aquat. Sci. 66: 949-958.

Bunbury J, Gajewski K, 2005. Quantitative analysis of freshwater ostracode assemblages in southwestern Yukon Territory, Canada. Hydrobiologia 545:117-128.

Bunbury J, Gajewski K 2009. Biogeography of freshwater ostracodes in the Canadian arctic archipelago. Arctic 62:324-332.

Canchola JA, Tang S, Hemyari P, Paxinos E, Marins E, 2017. Correct use of percent coefficient of variation (cv) formula for log-transformed data. MOJ Proteomics Bioinform 6:316-7.

CCME-Canadian Council of Ministers of the Environment, 2004. Canadian water quality guidelines for the protection of aquatic life. Phosphorus: Canadian Guidance Framework for the Management of Freshwater Systems. Canadian Council of Ministers of the Environment, Winnipeg. Available from: http://ceqg-rcqe.ccme.ca/download/en/205

CEC-Commission for Environmental Cooperation, Montréal, Québec, and Secretariat, 1997. Ecological regions of North America: toward a common perspective. Commission for Environmental Cooperation. Available from: http://www3. cec.org/islandora/en/item/1701-ecological-regions-northamerica-toward-common-perspective

Cerling TE, Pederson BL, Von Damm KL 1989. Sodium-calcium ion exchange in the weathering of shales: Implications for global weathering budgets. Geology 17:552-554.

Clague JJ, Mathews WH, Ryder JM, Hughes OL, Rutter NW, Jackson Jr. LE, Matthews Jr. JW, MacDonald GM, 1989. Quaternary Geology of the Canadian Cordillera, p. 40-42. In: R.J. Fulton (ed.), Quaternary Geology of Canada and Greenland. Geological Survey of Canada, Geology of Canada Series. 1-839. Canadian Government Publishing Centre. Ottawa, Canada.

Corbett JJ, Lack DA, Winebrake JJ, Harder S, Silberman JA, Gold M. 2010. Arctic shipping emissions inventories and future scenarios. Atmos. Chem. Phys. 10:9689-9704.

Côté G, Pienitz R, Velle G, Wang X, 2010. Impact of geese on the limnology of lakes and ponds from Bylot Is. Nunavut, Canada. Int. Rev. Hydrobiol. 95:105-129.

Dawes PR, Christie RL, 1991. Geomorphic regions, p. 29-56. In: H.P. Trettin (ed.), Geology of the Innuitian orogen and Arctic platform of Canada and Greenland. Geology of Canada Ottawa, Canada.

Dawson J, Winebrake DA, Harder JJ, Silberman S, Gold M, 2017. Shipping trends in Nunavut from 1990-2015. A report prepared for the Nunavut General Monitoring Program. Nunavut General Monitoring Program, Ottawa.
Devlin JE, 2010. Applications of paleolimnology in ecosystem monitoring for Sirmilik National park: Developing indicators of ecological integrity. Ms Thesis, University of Toronto.

Devlin JE, Finkelstein SA, 2011. Local physiographic controls on the responses of Arctic lakes to climate warming in Sirmilik National Park, Nunavut, Canada. J. Paleolimnol. 45:23-39.

Dittmar T, Kattner G, 2003. The biogeochemistry of the river and shelf ecosystem of the Arctic Ocean: a review. Marine Chem. 83:103-120.

Downing, J.A. and McCauley, E. 1992. The nitrogen:phosphorus relationship in lakes. Limnol. Oceanogr. 37:936-945.

Dranga SA, Hayles S, Gajewski K, 2018. Synthesis of limnological data from lakes and ponds across Arctic and Boreal Canada. Arctic Sci. doi:10.1139/as-2017-0039.

Dupont J, Clair TA, Gagnon C, Jeffries DS, Kahl JS, Nelson SJ, Peckenham JM, 2005. Estimation of critical loads of acidity for lakes in northeastern United States and eastern Canada. Environ. Monitor. Assess. 109:275-292.

Elser JJ, Bracken ME, Cleland EE, Gruner DS, Harpole WS, Hillebrand H, Ngai JT, Seabloom EW, Shurin JB, Smith JE, 2007. Global analysis of nitrogen and phosphorus limitation of primary producers in freshwater, marine and terrestrial ecosystems. Ecol. Lett. 10:1135-1142.

Environmental Canada, 1994a. Environmental Canada Manual of Analytical Methods: Major Ions and Nutrients, Vol 1. National Laboratory for Environmental Testing, Canadian Centre for Inland Waters, Burlington.

Environmental Canada, 1994b. Environmental Canada Manual of Analytical Methods: Trace Metals, Vol 2. National Laboratory for Environmental Testing, Canadian Centre for Inland Waters, Burlington.

Everett KR, 1980. Distribution and properties of road dust along the northern portion of the Haul Road, p. 101-128. In: J. Brown and R.L. Berg (eds.), Environmental engineering and ecological baseline investigations along the Yukon RiverPrudhoe Bay Haul Road. CRREL Report 80-19. U.S. Army Cold Regions Research and Engineering Laboratory, Hanover.

Forsius M, Posch M, Aherne J, Reinds GJ, Christensen J, Hole L, 2010. Assessing the impacts of long-range sulfur and nitrogen deposition on arctic and sub-arctic ecosystems. Ambio 39:136-147.

Gong W, Beagley SR, Cousineau S, Sassi M, Munoz-Alpizar R, Ménard S, Racine J, Zhang J, Chen J, Morrison H, Sharma S, 2018. Assessing the impact of shipping emissions on air pollution in the Canadian Arctic and northern regions: Current and future modelled scenarios. Atmos. Chem. Phys.1822:16653-16687.

Gould WA, Edlund S, Zoltai S, Raynolds M, Walke, DA, Maier H, 2002. Canadian Arctic vegetation mapping. Int. J. Remote Sensing 23:4597-4609.

Gould WA, Rayolds M, Walker DA, 2003. Vegetation, plant biomass, and net primary productivity patterns in the Canadian Arctic. J. Geophys. Res. 108:1-14.

Gunter RA, 2017. The impact of road dust on Arctic aquatic ecosystems, Northwest Territories, Canada. MS Thesis, Brock University.

Hadley KR, 2007. Assessing Thule Inuit impacts on High Arctic 
lakes and ponds: A paleolimnological approach. MS Thesis, Queen's University.

Hadley KR, Douglas MSV Lim D, Smol JP, 2013. Diatom assemblages and limnological variables from 40 lakes and ponds on Bathurst Is. and neighboring high Arctic Island. Int. Rev. Hydrobiol. 98:44-59.

Haley S, Klick M, Szymoniak N, Crow A, 2011. Observing trends and assessing data for Arctic mining. Polar Geogr. 34:37-61.

Hamilton PB, Gajewski K, Atkinson DE, Lean DRS, 2001. Physical and chemical limnology of 204 lakes from the Canadian Arctic Archipelago. Hydrobiologia 457:133-148.

Harrison JC, St-Onge MR, Petrov OV, Strelnikov SI, Lopatin BG, Wilson FH, Tella S, Paul D, Lynds T, Shokalsky SP, Hults CK, Bergman S, Jepsen HF, Solli A, 2011. Geological map of the Arctic / Carte géologique de l'Arctique, Map 2159A, scale 1:5 000 000. Geological Survey of Canada.

Havas M, Hutchinson TC, 1983. The Smoking Hills: natural acidification of an aquatic ecosystem. Nature 30:23-27.

Hessen DO, Tombre IM, van Geest G, Alfsnes K, 2017. Global change and ecosystem connectivity: How geese link fields of central Europe to eutrophication of Arctic freshwaters. Ambio 46:40-47.

Hines JE, Latour PB, Machtans CS, 2010. The effects on lowland habitat, breeding shorebirds and songbirds in the Banks Is. Migratory Bird Sancturay Number 1 by the growing colony of Lesser Snow Geese Chen caerulescens caerulescens. Canadian Wildlife Service Occasional Paper No. 118. Environment Canada, Ottawa.

Hodgson DA, 2005. Quaternary geology of Western Meta Incognita Peninsula and Iqaluit area, Baffin Is., Nunavut. Geol. Survey Can. Bull. 585:1-72.

ICP Waters Programme Centre, 2010. ICP Waters Programme Manual 2010. Norwegian Institute for Water Research, Oslo.

Johannesson KH, Lyons WB, 1995. Rare-earth element geochemistry of Colour Lake, an acidic freshwater lake on Axel Heiberg Is., Northwest Territories, Canada. Chem. Geol. 119:209-223.

Keatley BE, 2007. Environmental change in three distinct ecosystem types, Canadian High Arctic. PhD Thesis, Department of Biology, Queen's University.

Keatley BE, Douglas MSV, Smol JP, 2007. Limnological characteristics of a high Arctic oasis and comparisons Ellesmere Is. across Northern. Arctic 60:294-308.

Keatley BE, Douglas MS, Blais JM, Mallory ML, Smol JP, 2009. Impacts of seabird-derived nutrients on water quality and diatom assemblages from Cape Vera, Devon Is., Canadian High Arctic. Hydrobiologia 621:191-205.

Konhauser KO, Fyfe WS, Schultze-Lam S, Ferris FG, Beveridge TJ, 1994. Iron phosphate precipitation by epilithic microbial biofilms in Arctic Canada. Can. J. Earth Sci. 31:1320-1324.

Lamoureux SF, Gilbert R, 2004. Physical and chemical properties and proxies of high latitude lake sediments, p. 5387. In: J.P. Smol, R. Pienitz and M.S.V. Douglas (eds.), Long-term environmental change in Arctic and Antarctic lakes. Springer, Dordrecht.

Law KS, Stohl A, 2007. Arctic air pollution: Origins and impacts. Science 315:1537-1540.

Liang T, Aherne J, 2019. Critical loads of acidity and exceedances for 1138 lakes and ponds in the Canadian Arctic. Sci. Total Environ. 652:1424-1434.

Lim DSS, Douglas MSV, 2003. Limnological characteristics of 22 lakes and ponds in the Haughton crater region of Devon Island, Nunavut, Canadian High Arctic. Arct. Antarct. Alpi. Res. 35:509-519.

Lim DSS, Douglas MSV, Smol JP, 2005. Limnology of 46 lakes and ponds on Banks Is., N.W.T., Canadian Arctic Archipelago. Hydrobiologia 545:11-32.

Lim DSS, Douglas MSV, Smol JP, Lean DRS, 2001. Physical and chemical limnological characteristics of 38 lakes and ponds on Bathurst Is., Nunavut, Canadian high arctic. Int. Rev. Hydrobiol. 86:1-22.

Lougheed VL, Butler MG, McEwen DC, Hobbie JE, 2011. Changes in tundra pond limnology: Re-sampling Alaskan ponds after 40 years. Ambio 40:589-599.

Mallory ML, Fontaine AJ, Smith PA, Robertson MOW, Gilchrist HG, 2006. Water chemistry of ponds on Southampton Is., Nunavut, Canada: Effects of habitat and ornithogenic inputs. Arch. Hydrobiol. 166:411-432.

Maxwell JB, 1981. Climatic regions of the Canadian Arctic islands. Arctic 34:225-240.

McNeely RN, Dwyer L, Neimanis VP, 1979. Water quality sourcebook: A guide to water quality parameters. Environment Canada, Inland Waters Directorate, Ottawa: 89 pp.

Medeiros AS, Biastoch RG, Luszczek CE, Wang XA, Muir DCG, Quinlan R, 2012. Patterns in the limnology of lakes and ponds across multiple local and regional environmental gradients in the eastern Canadian arctic. Inland Waters 2:59-76.

Meier WN, Stroeve J, Fetterer F, 2007. Whither Arctic sea ice? A clear signal of decline regionally, seasonally and extending beyond the satellite record. Ann. Glaciol. 46:428-434.

Michelutti N, Blais JM, Mallory ML, Brash J, Thienpont J, Kimpe LE, Douglas MSV, Smol JP, 2010. Trophic position influences the efficacy of seabirds as metal biovectors. Proc. Natl. Acad. Sci. 107:10543-10548.

Michelutti N, Douglas MSV, Smol JP, 2003. Diatom response to recent climatic change in a high arctic lake Char Lake, Cornwallis Is., Nunavut. Global Planet. Change 38:257-271.

Michelutti N, Douglas MSV, Smol JP, 2007a. Evaluating diatom community composition in the absence of marked limnological gradients in the high Arctic: A surface sediment calibration set from Cornwallis Is. Nunavut, Canada. Polar Biol. 30:1459-1473.

Michelutti N, Douglas MSV, Lean DRS, Smol JP, 2002b. Physical and chemical limnology of 34 ultra-oligotrophic lakes and ponds near Wynniatt Bay, Victoria Is., Arctic Canada. Hydrobiologia 482:1-13.

Michelutti N, Wolfe AP, Briner JP, Miller GH, 2007b. Climatically controlled chemical and biological development in Arctic lakes. J. Geophys. Res. Biogeosci. 112:(G3).

Michelutti N, Wolfe AP, Vinebrooke RD, Rivard B, Briner JP. 2005. Recent primary production increased in Arctic lakes. Geophys. Res. Lett. 32:1-4.

Michelutti N, Douglas M, Muir D, Wang X, Smol JP, 2002a. Limnological characteristics of 38 lakes and ponds on Axel Heiberg Is., High Arctic Canada. Int. Rev. Hydrobiol. 87:385-399.

Moiseenko TI, Sharov AN, Vandish OI, Kudryavtseva LP, 
Gashkina NA, Rose C, 2009. Long-term modification of Arctic lake ecosystems: Reference condition, degradation under toxic impacts and recovery (case study Imandra Lakes, Russia). Limnologica 39:1-13.

Mortimer CH, 1941. The exchange of dissolved substances between mud and water in lakes. J. Ecol. 29:280-329.

Moser KA, Smol JP, MacDonald GM, 1998. Ecology and distribution of diatoms from boreal lakes in Wood Buffalo National Park, northern Alberta and the Northwest Territories, Canada. Hydrobiologia 23:25-43.

Neary BP, Dillon PJ, 1988. Effects of sulphur deposition on lakewater chemistry in Ontario, Canada. Nature 333:340-343.

Nürnberg GK, 1996. Trophic state of clear and colored, soft-and hardwater lakes with special consideration of nutrients, anoxia, phytoplankton and fish. Lake Reserv. Manage. 124:432-447.

Osterkamp TE, Romanovsky VE, 1999. Evidence for warming and thawing of discontinuous permafrost in Alaska. Permafr. Periglac. Process. 10:17-37.

Outridge PM, Hermanson MH, Lockhart WL, 2002. Regional variations in atmospheric deposition and sources of anthropogenic lead in lake sediments across the Canadian Arctic. Geochim. Cosmochim. Acta 66:3521-3531.

Overland JE, Hanna E, Hanssen-Bauer I, Kim SJ, Walsh JE, Wang M, Bhatt US, Thoman RL, 2017. Surface air temperature. Available from: https://www.arctic.noaa.gov/Report-Card/ Report-Card-2018/ArtMID/7878/ArticleID/783/Surface-AirTemperature

Paltan H, Dash J, Edwards M, 2015. A refined mapping of Arctic lakes using Landsat imagery. Int. J. Remote Sensing 36:5970-5982.

Payette S, Delwaide A, Caccianiga M, Beauchemin M, 2004. Accelerated thawing of subarctic peatland permafrost over the last 50 years. Geophys. Res. Lett. 31 L18208.

Peters GP, Nilssen TB, Lindholt L, Eide MS, Glomsrød S, Eide LI, Fuglestvedt JS, 2011. Future emissions from shipping and petroleum activities in the Arctic. Atmos. Chem. Phys.11:5305-5320.

Pienitz R, Doran PT, Lamoureux SF, 2008. Origin and geomorphology of lakes in the polar regions, p. 25-41. In: F.V. Warwick and J. Laybourn-Parry (eds.), Polar lakes and rivers: Limnology of Arctic and Antarctic aquatic ecosystems. Oxford University Press, Oxford

Pienitz R, Smol JP, Lean DRS, 1997a. Physical and chemical limnology of 59 lakes located between the southern Yukon and the Tuktoyaktuk Peninsula, Northwest Territories Canada. Can. J. Fish. Aquat. Sci. 54:330-346.

Pienitz R, Smol JP, Lean DRS, 1997b. Physical and chemical limnology of 24 lakes located between Yellowknife and Contwoyto Lake, Northwest Territories Canada. Can. J. Fish. Aquat. Sci. 54:347-358.

Pizzolato L, Howell SEL, Dawson J, Laliberté F, Copland L, 2016. The influence of declining sea ice on shipping activity in the Canadian Arctic. Geophys. Res. Lett. 43:146-154.

Plug LJ, Walls C, Scott BM, 2008. Tundra lake changes from 1978 to 2001 on the Tuktoyaktuk Peninsula, western Canadian Arctic. Geophys. Res. Lett. 35:1-5.

Polyakov IV, Walsh JE, Kwok R, 2012. Recent changes of Arctic multiyear sea ice coverage and the likely causes. Bull. Am. Meteorol. Soc. 93:145-151.
Prowse TD, Wrona FJ, Reist JD, Gibson JJ, Hobbie JE. Lévesque LMJ, Vincent WF, 2006. Climate change effects on hydroecology of arctic freshwater ecosystems. Ambio 35:347-58.

Rautio M, Dufresne F, Laurion I, Bonilla S, Vincent WF, Christoffersen KS, 2011. Shallow freshwater ecosystems of the circumpolar Arctic. Ecoscience 18:204-222.

Reist JD, Wrona FJ, Prowse TD, Power M, Dempson JB, Beamish RJ, King JR, Carmichael TJ, Sawatzky CD, 2006. General effects of climate change on Arctic fishes and fish populations. Ambio 35:370-380.

Roberts KE, Lamoureux SF, Kyser TK, Muir DCG, Lafrenière MJ, Iqaluk D, Pieńkowski AJ, Normandeau A, 2017. Climate and permafrost effects on the chemistry and ecosystems of High Arctic Lakes. Nat. Sci. Rep. 7:1-8.

Romanovsky VE, Drozdov DS, Oberman NG, Malkova GV, Kholodov AL, Marchenko SS, Moskalenko NG, Sergeev DO, Ukraintseva NG, Abramov AA, Gilichinsky DA, 2010. Thermal state of permafrost in Russia. Permafr. Perigl. Proc. 21:136-155.

Rothrock DA, Yu Y, Maykut GA, 1999. Thinning of the Arctic sea-ice cover. Geophys. Res. Lett. 26:3469-3472.

Rouse WR, Douglas MS, Hecky RE, Hershey AE, Kling GW, Lesack L, Marsh P, McDonald M, Nicholson BJ, Roulet NT, Smol JP, 1997. Effects of climate change on the freshwaters of Arctic and subarctic North America. Hydrol. Proc. 11:873-902.

Rühland KM, Smol JP, 1998. Limnological characteristics of 70 lakes spanning Arctic treeline from Coronation Gulf to Great Slave Lake in the Central Northwest Territories, Canada. Int. Rev. Hydrobiol. 141:137-141.

Rühland KM, Smol JP, Wang X, Muir DCG. 2003. Limnological characteristics of 56 lakes in the Central Canadian Arctic Treeline Region. J. Limnol. 62:9-27.

Sakamoto M, 1966. Primary production by phytoplankton community in some Japanese lakes and its dependence on lake depth. Arch. Hydrobiol. 62:1-28.

Schindler DW, Kalff J, Welch HE, Brunskill GJ, Kling H, Kritsch N, 1974. Eutrophication in the High Arctic - Meretta Lake, Cornwallis Island (75 N Lat.). J. Fish. Res. Board Can. 31:647-662.

Smith LC, Sheng Y, MacDonald GM, Hinzman LD, 2005. Disappearing arctic lakes. Science 308:1429-1429.

Sobek S, Tranvik LJ, Prairie YT, Kortelainen P, Cole JJ, 2007. Patterns and regulation of dissolved organic carbon: An analysis of 7,500 widely distributed lakes. Limnol. Oceanogr. 52:1208-1219.

Søndergaard M, Jensen JP, Jeppesen E, 2003. Role of sediment and internal loading of phosphorus in shallow lakes. Hydrobiologia 506:135-145.

Spatt PD, 1978. Seasonal variation of growth conditions on a natural and dust impacted Sphagnum (Sphagnaceae) community in northern Alaska. MS Thesis, University of Cincinnati.

Stewart KA, Lamoureux SF, 2011. Connections between river runoff and limnological conditions in adjacent high arctic lakes: Cape Bounty, Melville Is., Nunavut. Arctic 64:169182.

Stonehouse B, 1989. Polar ecology. Blackie, Glasgow: 222 pp. Surdu CM, Duguay CR, Prieto DF, 2016. Evidence of recent 
changes in the ice regime of lakes in the Canadian high Arctic from spaceborne satellite observation. Cryosphere 10:941-960.

Tarnocai C, 2003. Arctic permafrost soils, p. 3-17. In: R. Margesi (ed.), Permafrost soils. Springer, Berlin.

Thienpont JR, Rühland KM, Pisaric MFJ, Kokelj SV, Kimpe LE, Blais JM, Smol JP, 2013. Biological responses to permafrost thaw slumping in Canadian Arctic lakes. Freshwater Biol. 58 337-353.

Vincent WF, Laurion I, Pienitz R, Walter Anthony KM, 2012. Climate impacts on Arctic lake ecosystems, p. 27-42. In: C.R Goldman, M. Kumagai and R.D. Robarts (Eds.), Climatic change and global warming of inland waters: Impacts and mitigation for ecosystems and societies. J. Wiley \& Sons, Chichester.

Walker DA, Raynolds MK, Daniëls FJA, Einarsson E, Elvebakk A, Gould WA, Katenin AE, Kholod SS, Markon CJ, Melnikov ES, Moskalenko NG, Talbot SS, Yurtsev BA, CAVM Team, 2005. The Circumpolar Arctic vegetation map. J. Veget. Sci. 16:267-282.

Walvoord MA, Striegl RG, 2007. Increased groundwater to stream discharge from permafrost thawing in the Yukon River basin: Potential impacts on lateral export of carbon and nitrogen. Geophys. Res. Lett. 34:1-6.

Westover KS, Moser KA, Porinchu DF, MacDonald GM, Wang $\mathrm{X}, 2009$. Physical and chemical limnology of a 61-lake transect across mainland Nunavut and southeastern Victoria Is., Central Canadian Arctic. Arch. Hydrobiol. 175:93-112.

Wetzel RG, 2001. Salinity of inland waters, p. 169-186. In: R.G. Wetzel RG, Limnology. Elsevier, Amsterdam.

Whalen SC, Cornwell JC, 1985. Nitrogen, phosphorus, and organic carbon cycling in an Arctic lake. Can. J. Fish. and Aquat. Sci. 42:797-808.

Wiken, Ed, Francisco J.N., and Griffith, G. 2011. North American Terrestrial Ecoregions - Level III. Commission for Environmental Cooperation, Montreal, Canada

Wilson SE, Gajewski K, 2002. Surface-sediment diatom assemblages and water chemistry from 42 subarctic lakes in the southwestern Yukon and northern British Columbia, Canada. Ecoscience 9:256-270.

Wolfe AP, Cooke CA, Hobbs WO, 2006. Are current rates of atmospheric nitrogen deposition influencing lakes in the eastern Canadian Arctic? Arct. Antarct. Alp. Res. 38:465-476.

Zhang X, Meyer T, Muir DC, Teixeira C, Wang X, Wania F, 2013. Atmospheric deposition of current use pesticides in the Arctic: Snow core records from the Devon Island Ice Cap, Nunavut, Canada. Environ. Sci. Processes Impacts 15:2304-2311.

Zhu L, Anello R, Rühland KM, Pisaric MFJ, Kokelj S, Prince T, Smol JP, 2019. Impacts of road dust on small subarctic lake systems. Arctic 72:337-484. 